\title{
39. MINERALOGY AND GEOCHEMISTRY OF SELECTED ALBIAN SEDIMENTS FROM THE BAY OF BISCAY, DEEP SEA DRILLING PROJECT LEG 48
}

\author{
Frédéric Mélières, Laboratoire de Géologie Dynamique de l'Université Pierre et Marie Curie, Paris, France
}

\section{INTRODUCTION}

Albian/Aptian sediments from the Bay of Biscay, recovered during DSDP Leg 48 , are characterized by a cyclicity in their lithology. This cyclicity generally consists of alternations of dark gray to black carbonaceous mudstones and greenish gray calcareous mudstones (see Site Chapters). The dark layers are similar, in their lithology, to the "black shales," a widespread facies in the Atlantic Cretaceous deposits, as established by previous DSDP Legs $14,36,40$, and 41.

In the deep-water sediments of Hole 400A, the dark layers are characterized by an organic carbon content value averaging 0.5 to 2 per cent of the sediment (Deroo et al., this volume); shipboard optical studies estimated a carbonaceous ("black material") content ranging from 5 to 20 per cent of the sediment. It was thus obvious that an important part of the "black material" consisted of unidentified inorganic constituents; finely divided pyrite or hydrotroilite were evoked. In order to try to resolve the problem, a detailed X-ray mineralogy study was carried on 122 samples taken every five $\mathrm{cm}$ in the following selected sequences:

1) Hole 400A, Core 66 (lower Albian), Section 3: 27 samples. This hole was drilled at the foot of the Meriadzek Terrace, in 4473 meters of water; the lithologic sequence studied is interpreted as a deep sea-water deposit (see Site Chapter).

2) Hole 402A, Core 24 (lower Albian), Sections 1 through 5: 95 samples. This hole was drilled in a spur of the Armorican Slope, north of the Meriadzek Terrace in 2385 meters of water. Hole 402A Albian sediments are interpreted as shallow-water deposits (see Site Chapter).

The samples were chosen in order to obtain a continuous control on the mineralogical assemblages throughout sedimentary cycles, and to compare the deep- and the shallow-water depositional conditions, in sediments as contemporary as possible. Figure 1 shows the physiographic position of Sites 400 and 402 in the paleogeographic conditions thought to have prevailed during the Albian times. The position of the samples with regard to lithology appears on Figures 2 and 3.

\section{ANALYTICAL METHODS}

\section{X-Ray Diffractometry}

Qualitative and quantitative analysis were carried out on bulk sediment. The analytical procedure used, basically operating on non-oriented powder with the use of an internal standard $(\mathrm{NaF})$ for quantitative estimation, is described in detail elsewhere (Mélières, 1974). A resumé of the basic steps is given in "X-ray mineralogy studies, Leg 41 " (Mélières, 1978).

\section{Optical Analysis}

Both optical microscope (smear slides) and SEM were used for morphological investigations. X-ray microprobe analysis was carried out on selected samples.

\section{Chemical Analysis}

In order to attempt a better interpretation of the mineralogical data, geochemical analyses were carried out on selected samples. Major element content was determined by means of XRF at Société Nationale Elf Aquitaine, and organic carbon content was determined with a LECO apparatus at Institut Français du Pétrole.

\section{RESULTS AND DISCUSSION}

The mineralogical and geochemical data are graphically represented in Figures 2 (Hole 400A) and 3 (Hole 402A).

\section{Hole 400A, Core 66, Section 3}

The section studied belongs to a sedimentary sequence consisting of alternations, on a metric scale, of black carbonaceous mudstones and greenish to bluish gray calcareous mudstones constituting the Aptian/Albian deposits (see Site Chapter).

\section{Terrigenous Material}

The terrigenous material consists mainly of quartz (average content value $10 \%$ ), illite $(10 \%)$, smectite (35\% to $50 \%$ ), and small amounts of chlorite (less than $1 \%$ ). Feldspars, usually present in such a suite, are absent here. The smectite is a beidellite, as shown by DTA data ${ }^{1}$ (second endothermic peak at $580^{\circ} \mathrm{C}$; strong exothermic peak at $900^{\circ} \mathrm{C}$ ), and contains potassium as interlayer cations (XRF data balance for $\mathrm{K}_{2} \mathrm{O}$ ); this smectite therefore was probably derived, on land, from micaceous and/or illitic material, through intense alteration (pedogenetic processes). The small grain size of the terrigenous material (less than 20 $\mu \mathrm{m})$ and its high maturation (absence of feldspar), suggest that the continental sources were distant and had little relief.

All the constituents of the terrigenous material show the same trend in the variation of their content. The greenish gray calcareous mudstones are characterized by a constant value of these contents (quartz 7-8\%; illite $8-9 \%$; smectite $35 \%$; chlorite less than $0.5 \%$ ) suggesting calm depositional conditions, which is supported by the absence of any primary sedimentary structure, and the presence of bioturbations (see Site Chapter). The terrigenous material

\footnotetext{
${ }^{1}$ Two samples, 400A-66-3, $111 \mathrm{~cm}$ and $400 \mathrm{~A}-66-3,148 \mathrm{~cm}$, chosen in the two different lithologies, were submitted for DTA analysis and yielded identical results.
} 


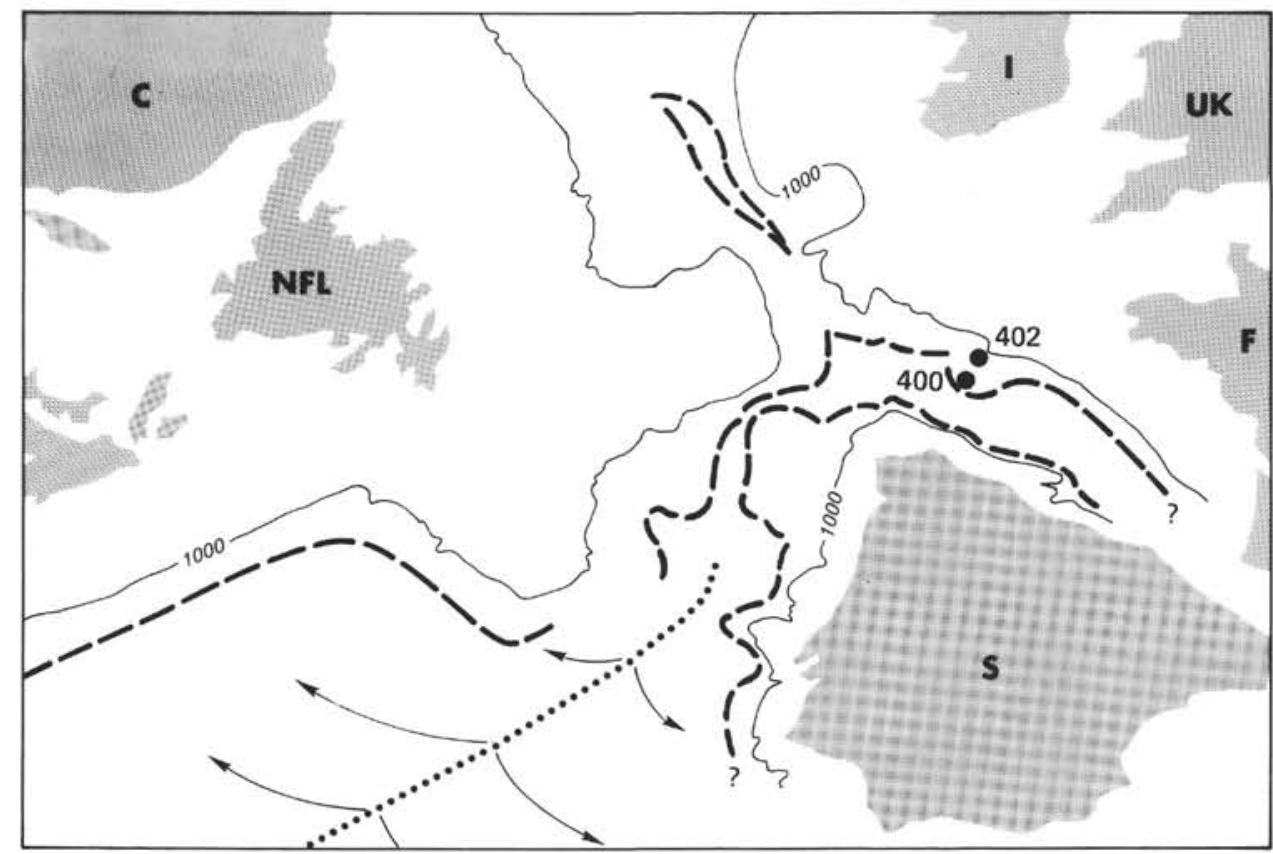

Figure 1. Location of DSDP Sites 400 and 402 in a tentative Albian paleogeographic frame (J-Anomaly, 112 m.y.). The heavy dashed line shows the probable limit of continental blocks, usually sketched from the present-day 4000-meter isobath; light continuous line shows present-day 1000-meter isobath (schematized from Olivet, 1978).

content values increase significantly in the two dark carbonaceous mudstone layers; in the lower one (base of the section) this increase is more pronounced than in the upper one $(71 \mathrm{~cm}$ to $86 \mathrm{~cm})$, but relative proportions of the constituents remain fairly constant, suggesting that the depositional process for both dark layers was the same, changing only in intensity. According to shipboard description and optical observation through binocular microscope, the black layers are finely laminated. Although compaction actually emphasized the laminated structure of these layers almost devoid of carbonate (see below), the lamination suggests a settling through moderate but efficient bottom current.

The constancy of the mineralogical spectrum composition of the terrigenous material (nature and relative proportions of the minerals) throughout the section, indicates that this material was derived from the same continental sources, as well during the black layers' deposition as during that of the greenish gray calcareous mudstones.

\section{Carbonates}

The carbonate minerals are exclusively represented by calcite, mainly from coccoliths and microspicules. The good X-ray crystallinity (width at half height of [104] calcite diffraction peak), together with the lack of magnesium in the calcite lattice $\left(\mathrm{MgCO}_{3}\right.$ mole, less than $0.1 \%$ ), suggest either that the calcite was diagenetically recrystallized, or that calcitic debris underwent dissolution-recrystallization processes through deep-water settling. The former hypothesis seems unlikely in such clayey lithology; the latter appears more probable in the light of personal underway studies on biogenic calcite crystallinity of planktonic organisms. The absence of any other mineralogical form of calcium carbonate (Mg-calcite, aragonite) is consistent with deep water depositional conditions.

The calcite content value is fairly constant in the greenish gray calcareous mudstone, where it averages 20 per cent. ${ }^{2}$ This value drops conspicuously within the black layers, reaching a few per cent in the upper one, and actually 0 per cent in the lower one. Although these variations are indeed remarkable, it has to be noted that they are progressive, no break appearing in the calcite content curve. This would appear to obviate the possibility that any high-energy phenomenon (such as turbidity currents) occurred during the deposition of sediments.

The cause of the calcite content variations appears critical in the understanding of the cyclicity of the depositional processes, and this point needs to be briefly discussed.

Decrease in phytoplankton activity (calcite here consists essentially of coccoliths) may indeed result from a decrease in the temperature of surficial waters, because coccoliths are known to develop preferably in rather warm waters (McIntyre et al., 1967). However, it is difficult to imagine a

${ }^{2}$ This value (XRD data) may be slightly low, as shown by the dashed line in the calcite column of Figure 2, representing $\mathrm{CaCO}_{3}$ content value calculated from $\mathrm{CaO}$ content (XRF data). The calculation is justified by the fact that the smectite, the only possible efficient host for calcium, is completely devoid of this element (see geochemical data, lower black layer. Figure 2). Therefore, practically all the calcium must be involved in carbonate structures, and the discrepancy between XRD and XRF calcite curves suggests either underestimation of the calcite content value by $\mathrm{XRD}$, or the existence of a (problematic) amorphous carbonate phase. 


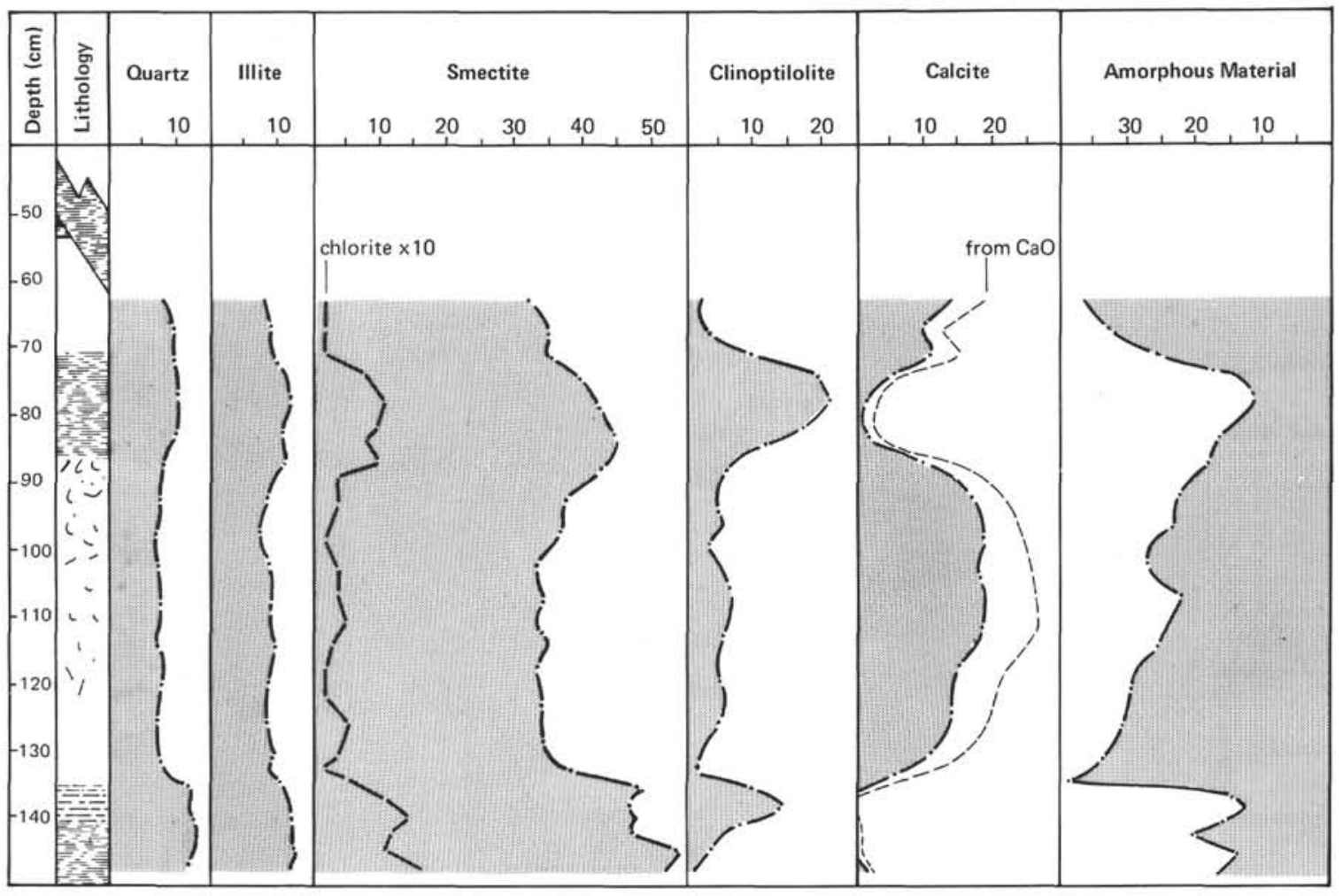

BULK X-RAY MINERALOGY

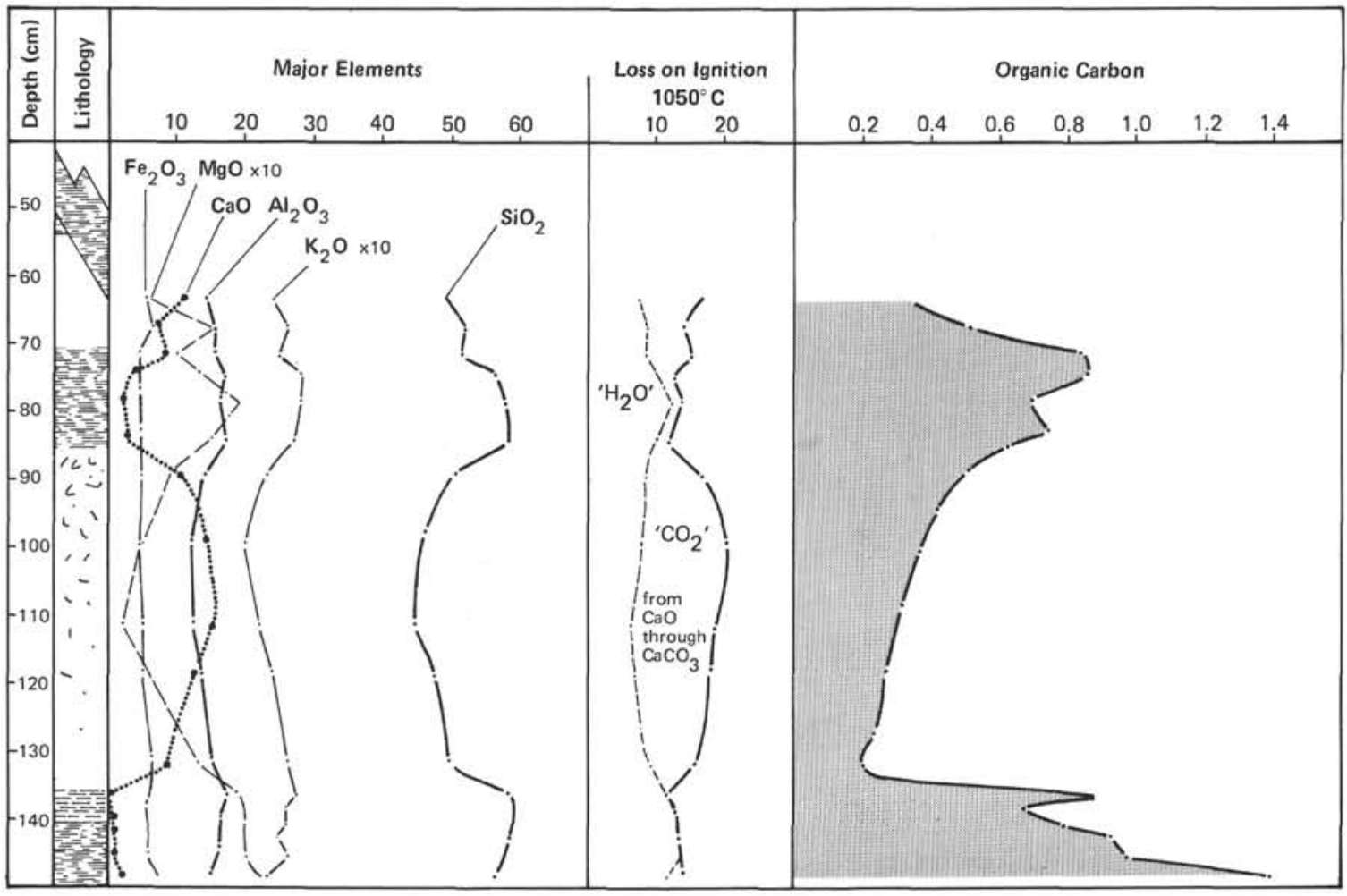

GEOCHEMISTRY

Figure 2. Analytical data, Hole 400A, Core 66, Section 3. 


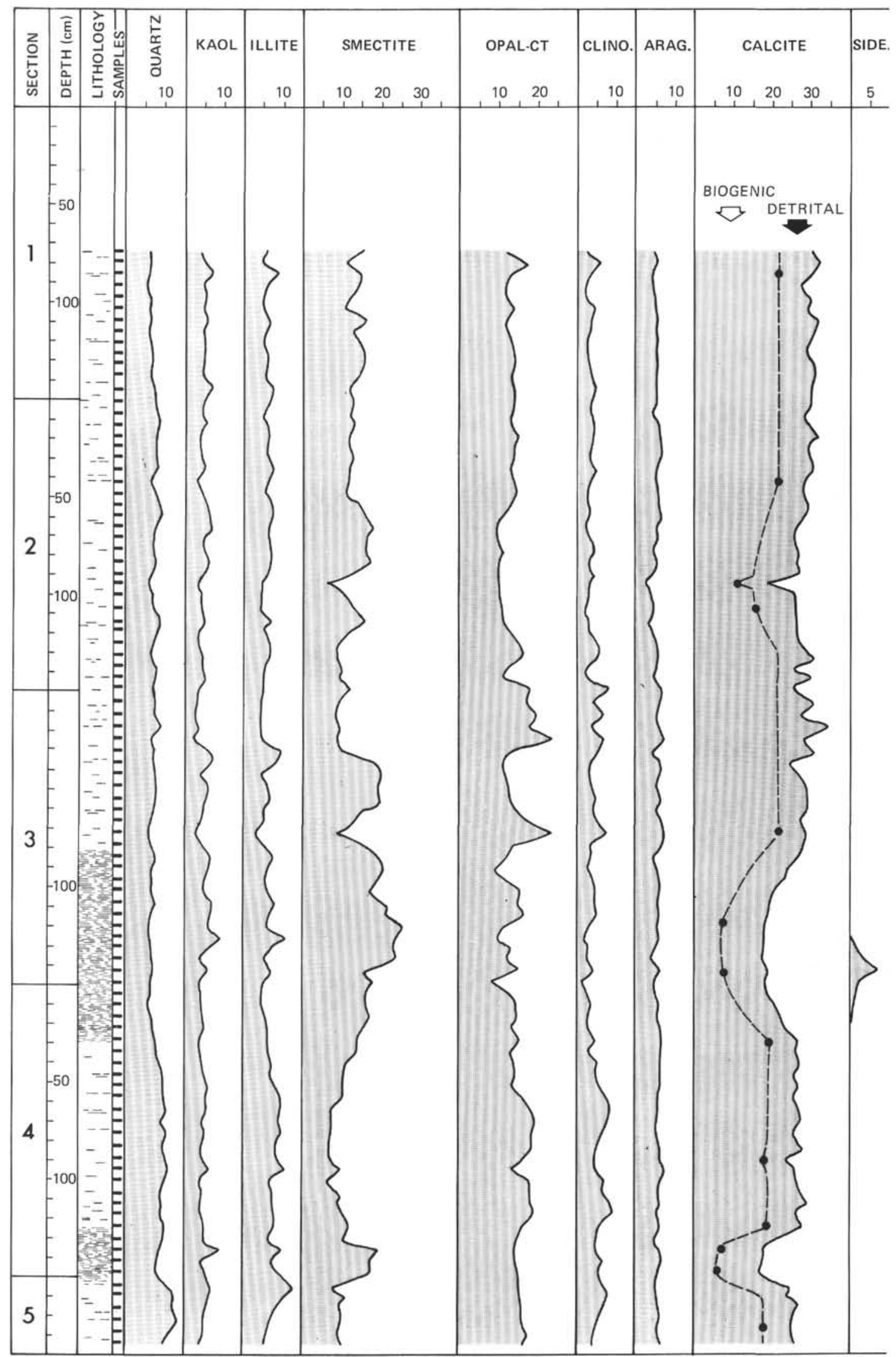

Figure 3. Bulk X-ray mineralogy and geochemistry data, Hole 402A, Core 24. 


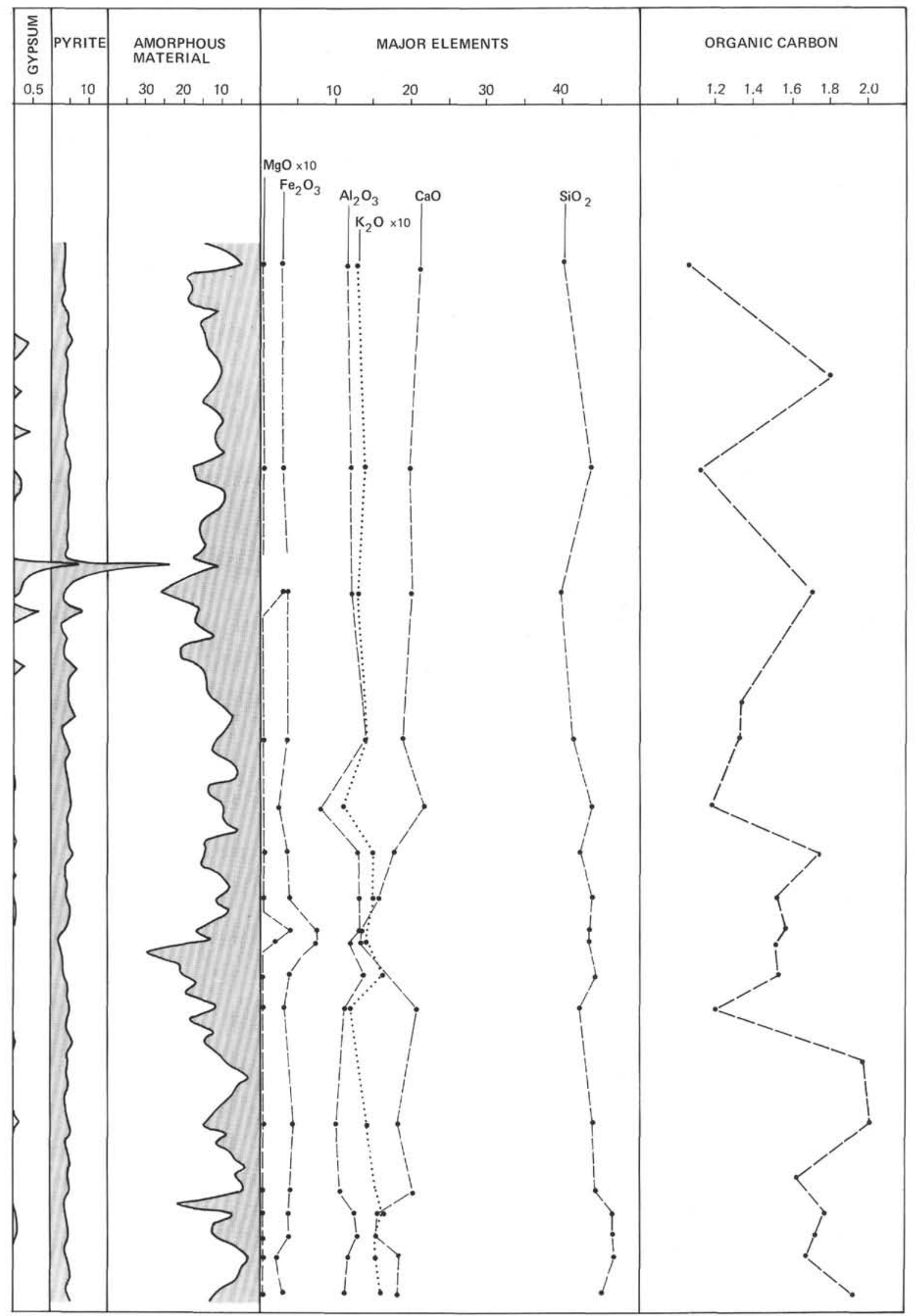

Figure 3. Continued. 
cooling severe enough to stop completely $(135 \mathrm{~cm}$ to $145 \mathrm{~cm}$, in the section studied) or almost completely $(75 \mathrm{~cm}$ to $85 \mathrm{~cm}$ ) the biogenic calcite production. Therefore, although fluctuations in biogenic calcite production are not to be discarded, as a model it seems unlikely that such hypothetic fluctuations are able to account for the calcite content variations observed.

The eventuality of post-depositional calcite dissolution through early diagenetic processes, for instance in an aggressive sedimentary medium, characterized by low $p \mathrm{H}$ value resulting from the evolution of the organic matter, seems unlikely because (1) the organic debris (vegetals, as we shall see below) do not show any trace of corrosion, and (2) the organic matter content is much too low (see geochemical data, Figure 2) to explain such a process. Calcite surely did not disappear after the settling of the sediment through diagenesis, because in that case, the calcium released (at least a part of it) would appear in the geochemical data; this is not observed (Figure 2).

The hypothesis of calcite dilution by an increase in the input of another constituent of the sediment (for instance clinoptilolite, whose content variation shows an opposite trend to that of calcite) must also be discarded, because an increase of clinoptilolite content would have affected the abundance curves of the other constituents (terrigenous material) in the same way (decrease) as that of calcite. Moreover, at the extreme base of the section, a minimum of clinoptilolite faces the low values of the calcite content.

Consequently, it seems that the only mechanism able to account for the calcite content variations is the dissolution of calcitic tests before reaching the bottom of the sea. Such a dissolution implies a periodic modification of the environmental conditions in a sense that the water masses became cyclically aggressive toward calcium carbonate.

\section{Clinoptilolite}

This zeolite, the true clinoptilolitic nature of which was checked by classical heat treatment $\left(500^{\circ}\right.$ for 4 hours), occurs throughout the studied section. It was diagenetically formed by infilling and replacement of radiolarian tests as clearly demonstrated in Figures 4, 5, 6. The mineral does not result here from transformation of any volcanic material, as it is often believed to happen in marine sediments.

The infilling of radiolarian tests implies the availability of ionic material (mainly silica) within the sediment; such material probably partly resulted from dissolution of biogenic siliceous remains, as indicated by dissolution marks clearly visible on radiolarian tests (Figure 7) ${ }^{3}$ It seems therefore that the abundance of clinoptilolite may be used here as an indicator of siliceous plankton productivity controlled by the availability of nutrients and silica in surficial waters. Nutrients do not appear to have been a limiting factor during Albian time, as suggested by the normal development of calcareous plankton and the presence of phosphate grains within the sediment, as it will be seen below ("amorphous material"). Therefore, the

\footnotetext{
${ }^{3}$ Clinoptilolite crystal growth needs minor amounts of alumina (12\%); this alumina is thought to derive from amorphous aluminosilicates (see below, "amorphous material"').
}

main controlling factor of the development of radiolarians seems to have been the availability of silica in surficial waters. Consequently, it is thought that the abundance of clinoptilolite may reasonably indicate the abundance of silica in the surficial waters during Albian time.

Quantitative XRD measurement of clinoptilolite abundance was carried out using a special curve $[(020)$ clinoptilolite $/(200) \mathrm{NaF}]_{\mathrm{XRD}}=\mathrm{f}$. [ clinoptilolite $\left./ \mathrm{NaF}\right]_{\text {mass }}$, calibrated by means of the clinoptilolite of the sediment in the studied section (Core 66, Section 3), isolated from a clinoptilolite-rich sample $(78 \mathrm{~cm})$. The clinoptilolite content value averages 5 per cent in the greenish gray calcareous mudstone, where it may reach 20 per cent in the black carbonaceous mudstone. The trend of its abundance variation appears conspicuously opposite to that of calcite.

Assuming that clinoptilolite abundance indicates the abundance of silica in the surficial waters during Albian time, the matching of silica-rich water inflow with (1) bottom current activity resulting in laminated structures within the black layers, and (2) modification of the environmental conditions, accounting for calcite dissolution before reaching the bottom of the sea, is quite consistent, as will be seen later.

\section{Pyrite}

Although some micrometric octahedrons of pyrite are sometimes visible in SEM photographs of sediments from the black carbonaceous mudstones (Figure 7), no trace of pyrite was detected through XRD (detection limit 1\%). The black carbonaceous mudstones therefore do not appear to have been deposited under especially reducing conditions, in an anoxic medium.

\section{Amorphous Material}

The amorphous material content value was tentatively estimated by subtracting the total amount of crystallized constituents from 100. Such a procedure actually yields only rough values, especially in clayey lithologies. Nevertheless, the resulting curve (Figure 2) shows a conspicuously opposite trend to that of organic carbon; because the latter came from terrestrial plant fragments (see below), it is concluded that the amorphous material is not terrigenous in origin.

\section{Organic Matter}

Microscopic investigations show that organic matter is composed mainly of terrestrial plant fragments (Figures 8 and 9). The fragments are well preserved in their delicate structures, looking sometimes as fresh as those from Recent (3000 years) peat. In smear slides, large fragments always appear black (carbonized) and therefore contribute to the dark color of the sediment. The fragments are more abundant in the black carbonaceous mudstones than in the greenish gray calcareous mudstones. This abundance variation is emphasized by the organic carbon content curve (Figure 2), which, using a correspondence factor of 2 (Trask, 1939), allows us to estimate the abundance of the plant fragments to be about 2 per cent in the black layers, and about 0.5 to 1 per cent in the calcareous mudstones. This trend is in good agreement with the increase of the terrigenous influence during the period of deposition of the black carbonaceous mudstones. 

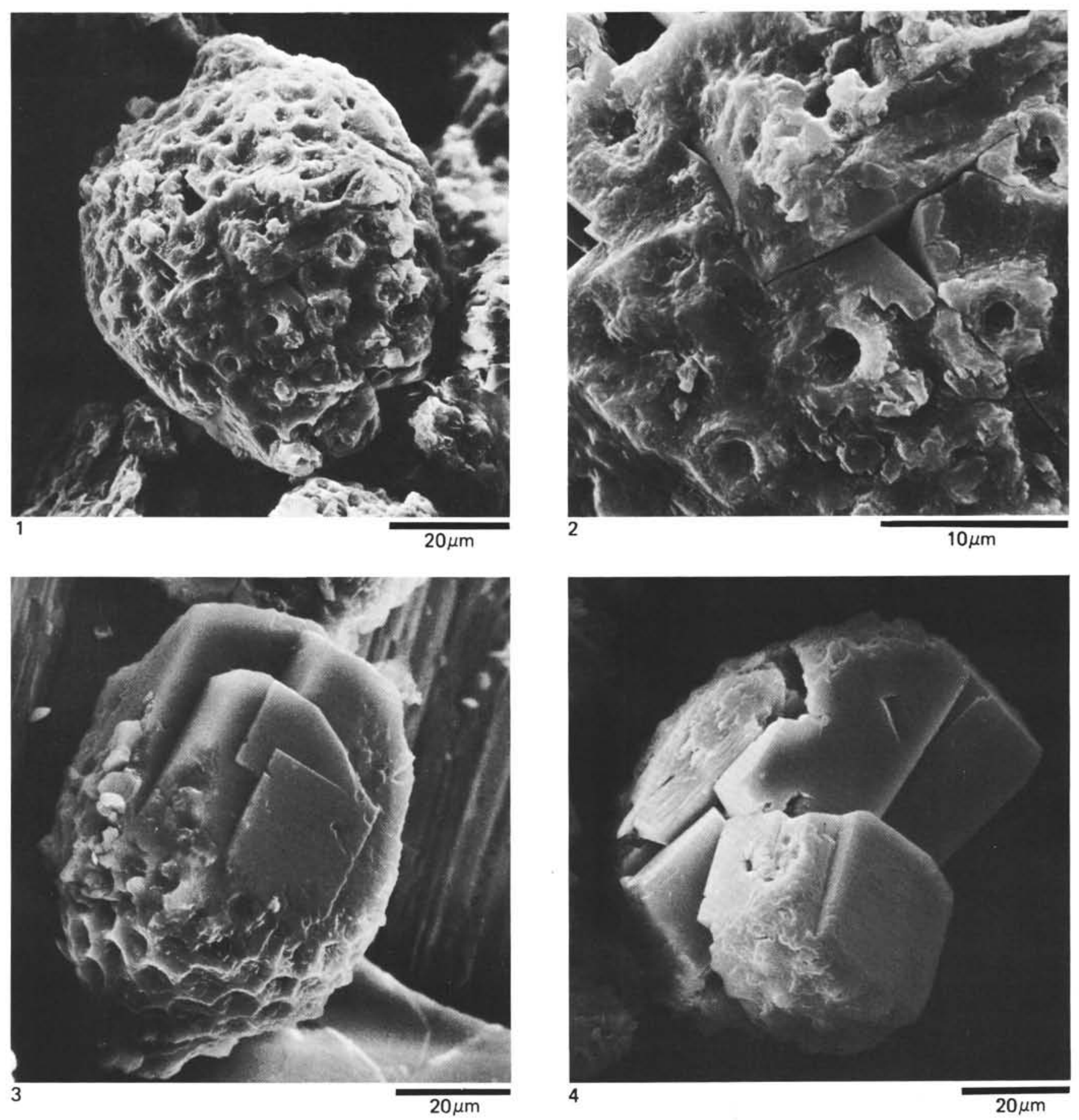

Figure 4. Examples of clinoptilolite crystals grown by infilling and replacement of radiolarian tests. Photo 2 is a detail of Photo 1 (Sample 400A-66-3, $136 \mathrm{~cm}$ ), showing the junction of monocrystals. Note the characteristic shape of the clinoptilolite crystal in Photo 3 (Sample 400A-66-3, $78 \mathrm{~cm}$ ). Photo 4 (Sample 400A-66-3, $78 \mathrm{~cm}$ ) shows the break up of internal molds, releasing monocrystalline clinoptilolite fragments as they appear in smear slides (see Figure 6). SEM.

\section{Phosphates}

Rare phosphate grains contribute to the composition of the amorphous material, as shown by SEM and X-ray microprobe investigations (Figure 10). The grains are relatively more abundant in the calcareous mudstones than in the black carbonaceous mudstones. Although they do not contribute significantly to the total amount of the amorphous material, their presence indicates that there was no lack of nutrients in the water mass.

\section{Other Amorphous Constituents}

Combining the mineralogical and the geochemical data, we have attempted to characterize the composition of the amorphous material. This tentative speculation concerns the 

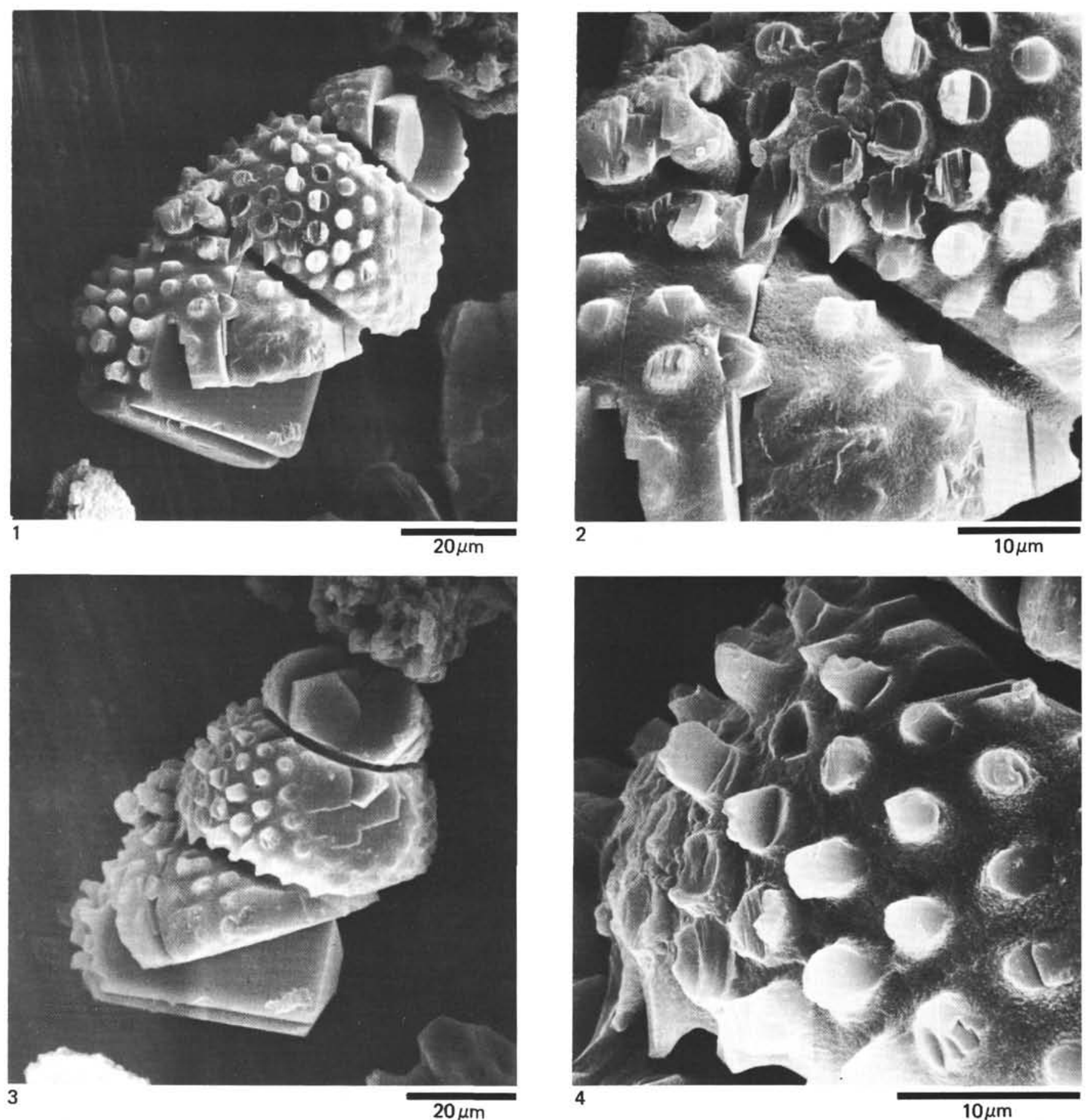

Figure 5. Clinoptilolite filling a radiolarian test (Sample 400A-66-3, $136 \mathrm{~cm}$ ). Photo 3 shows the same internal mold as Photo 1, from another view angle. Photos 2 and 4 are details, respectively, of Photos 1 and 3. Note that the crystal lattice develops throughout the chambers (Photo 2). Perfect clinoptilolite crystal shape constitutes the base of the mold (Photo 3). SEM.

sediments of the middle part of the calcareous mudstone zone, between 95 and $130 \mathrm{~cm}$, where the composition of the sediment does not show any significant variation.

Within this zone, the amorphous material content value averages 25 per cent. According to the structural formulas of the minerals involved, the following rough calculation was made, in order to estimate the amount of chemical elements involved in the crystallized structures:

\begin{tabular}{lcccc}
\hline Minerals & $\begin{array}{c}\text { Average } \\
\text { Content }\end{array}$ & $\mathrm{SiO}_{2}$ & $\mathrm{Al}_{2} \mathrm{O}_{3}$ & $\mathrm{Fe}_{2} \mathrm{O}_{3}$ \\
\hline Quartz & 8 & 8 & 0 & 0 \\
Clinoptilolite & 5 & 3 & 0.7 & 0.1 \\
Illite & 9 & 5 & 2.8 & 0.4 \\
Smectite & 35 & 17 & 7.5 & 1.4 \\
Calcite & 18 & $\underline{0}$ & $\underline{0}$ & $\frac{0}{1.9}$ \\
Total & $\overline{18}$ & 33 & 11 & 1.9 \\
\hline
\end{tabular}



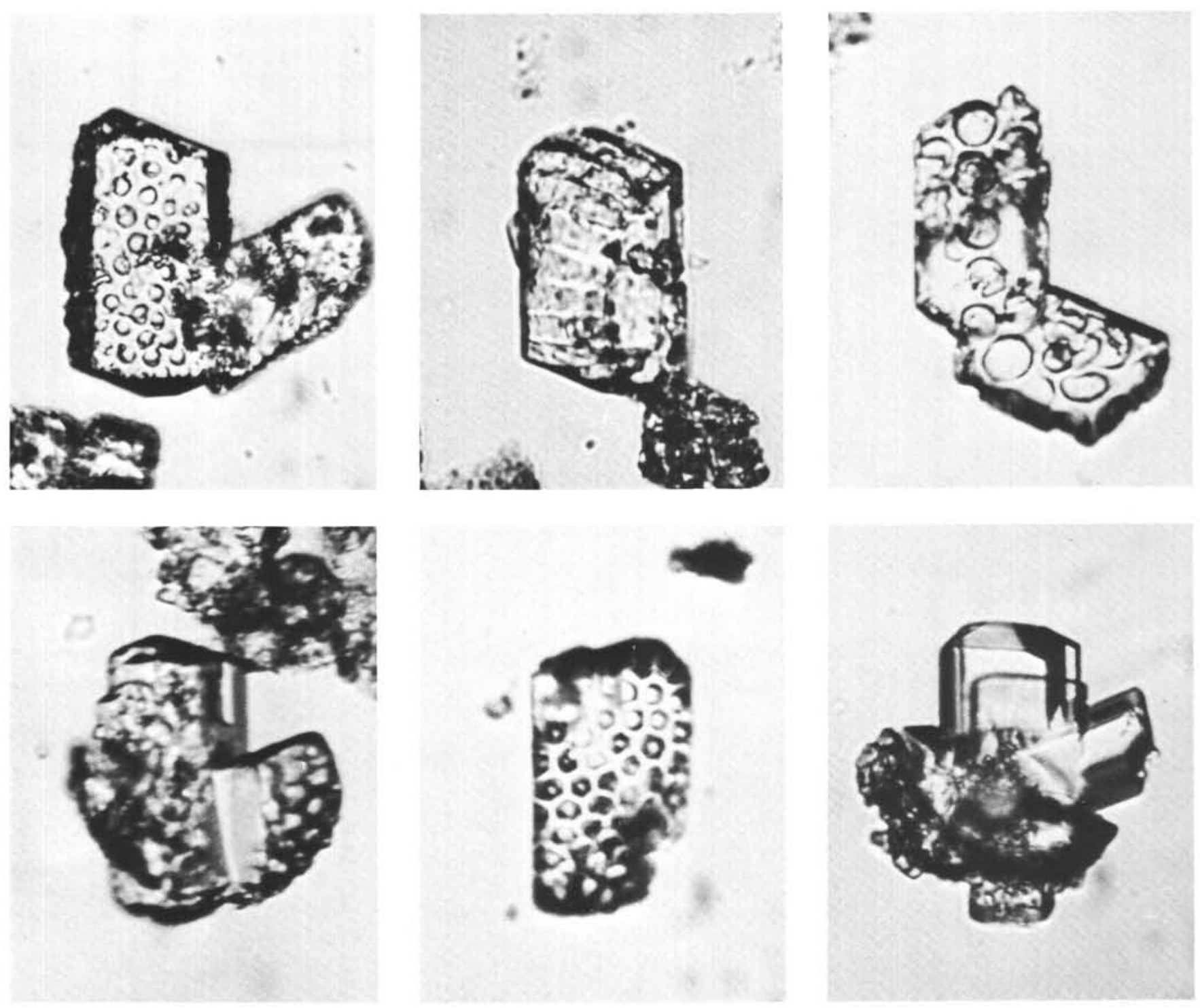

Figure 6. Examples of clinoptilolite crystals resulting from the break up of internal molds of radiolarian tests, as they usually appear in smear slides (Section 400A-66-3, various depths). Optical microscope, $G=400(2 \mathrm{~cm}=50 \mu \mathrm{m})$.

The total amount of crystallized $\mathrm{SiO}_{2}$ is 33 per cent, whereas chemical analysis yields 47 per cent $\mathrm{SiO}_{2}$; thus 14 per cent $\mathrm{SiO}_{2}$ is involved in amorphous minerals. The total amount of crystallized $\mathrm{Al}_{2} \mathrm{O}_{3}$ is 11 per cent where chemical analysis yields 13 per cent $\mathrm{Al}_{2} \mathrm{O}_{3}$; therefore, 2 per cent $\mathrm{Al}_{2} \mathrm{O}_{3}$ is involved in amorphous minerals. Because $\mathrm{Al}_{2} \mathrm{O}_{3}$ is unlikely to occur alone, it must be involved in colloidal aluminosilicates; assuming an approximative value 2 for the $\mathrm{SiO}_{2} / \mathrm{Al}_{2} \mathrm{O}_{3}$ ratio in these aluminosilicates, this yields 6 per cent colloidal aluminosilicates, leaving 10 per cent $\mathrm{SiO}_{2}$ as amorphous silica, thought to be of biogenic origin.

The total amount of crystallized $\mathrm{Fe}_{2} \mathrm{O}_{3}$ is 2 per cent; chemical analysis yields 5 per cent $\mathrm{Fe}_{2} \mathrm{O}_{3}$ and therefore 3 per cent $\mathrm{Fe}_{2} \mathrm{O}_{3}$ is involved in amorphous minerals, probably as oxides and/or hydroxides.

The organic matter represents about 1 per cent, as previously shown. The remainder: $[25 \%-(10 \%+6 \%+$ $3 \%+1 \%)=5 \%]$ consists either of unspecified amorphous minerals, which might well be (problematic) carbonates, as already suggested by the discrepancy between the calcite curve from XRD and from XRF data (see Figure 2), or ... failure in the discussion.

Finally, the average composition of the amorphous material within the calcareous mudstone zone may be estimated as follows:

\begin{tabular}{lr}
\hline Biogenic silica & $10 \%$ \\
Colloidal aluminosilicates & $6 \%$ \\
Iron oxides and/or hydroxides & $3 \%$ \\
Organic matter & $1 \%$ \\
Unspecified & $5 \%$ \\
\hline
\end{tabular}

Although this tentatively may appear hazardous, it brings some light on the nature of the constituents of the amorphous phase. It appears, for instance, that a large part of the amorphous material is not terrigenous in origin; this is 

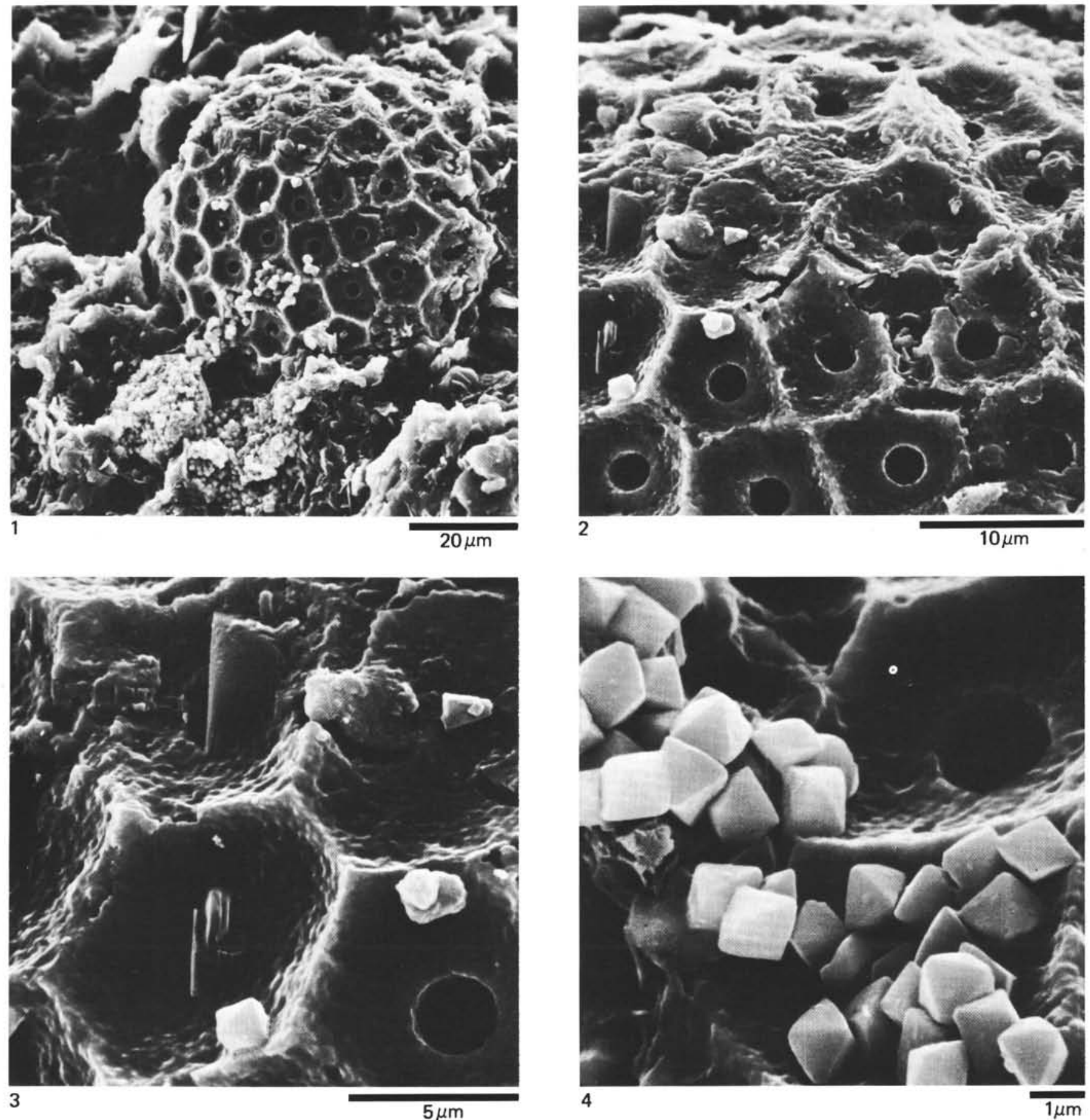

Figure 7. Test of radiolarian showing marks of intense corròsion (Sample 400A-66-1, $19 \mathrm{~cm}$ ). Photos 1 through 4 are successive close-ups. Minute octahedrons of pyrite rarely appear; they do not aggregate in framboids as is the rule in Albian sediments from Hole $402 \mathrm{~A}$ in continental shelf (see Fig. 13); this pyrite is not detected by XRD. SEM.

remarkably consistent with the trend of variation of the amorphous material content as estimated by XRD.

\section{Summary, Hole 400A}

The sediments constituting the sequence studied (Hole 400A, Core 66, Section 3, early Albian) were deposited in deep-water conditions but above the CCD, as suggested by the nature of the carbonate phase. These sediments consist mainly of fine-grained terrigenous material (smectite, illite, and quartz) marked by chlorite which is non-resistant to weathering; this indicates that (at least a part of) the material originated from rather cold (thus northern?) areas. The small grain size indicates that the depositional conditions were rather calm.

The amount of terrigenous material increased cyclically, as a result of an increase in water current transportation. The change, however, was not catastrophic, and is interpreted more likely to have resulted from an increase in 


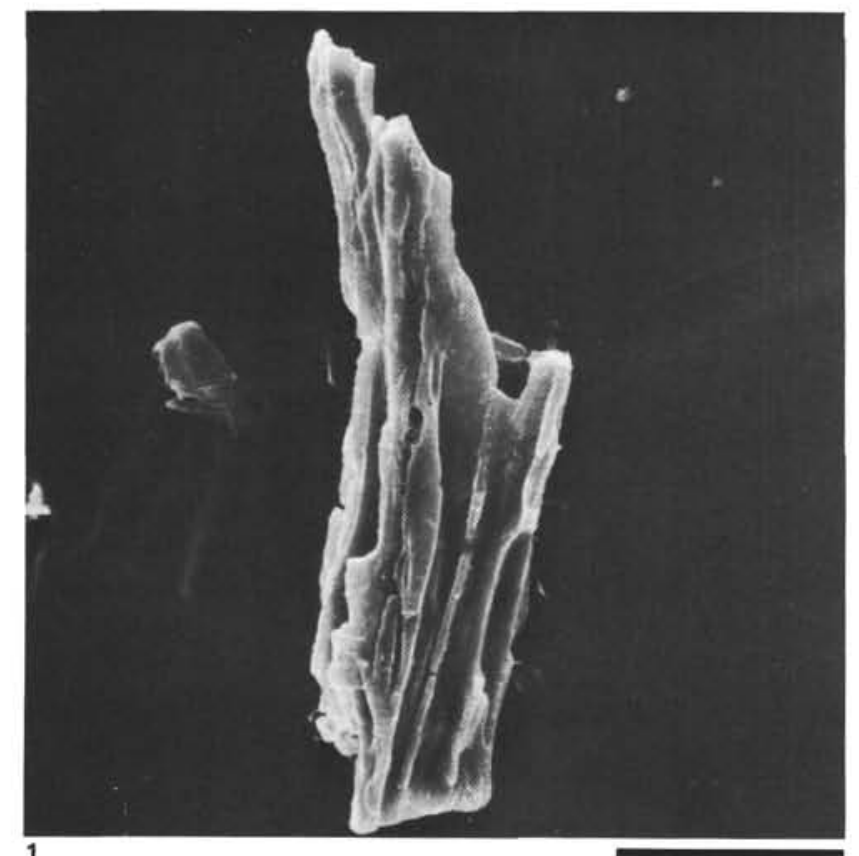

1

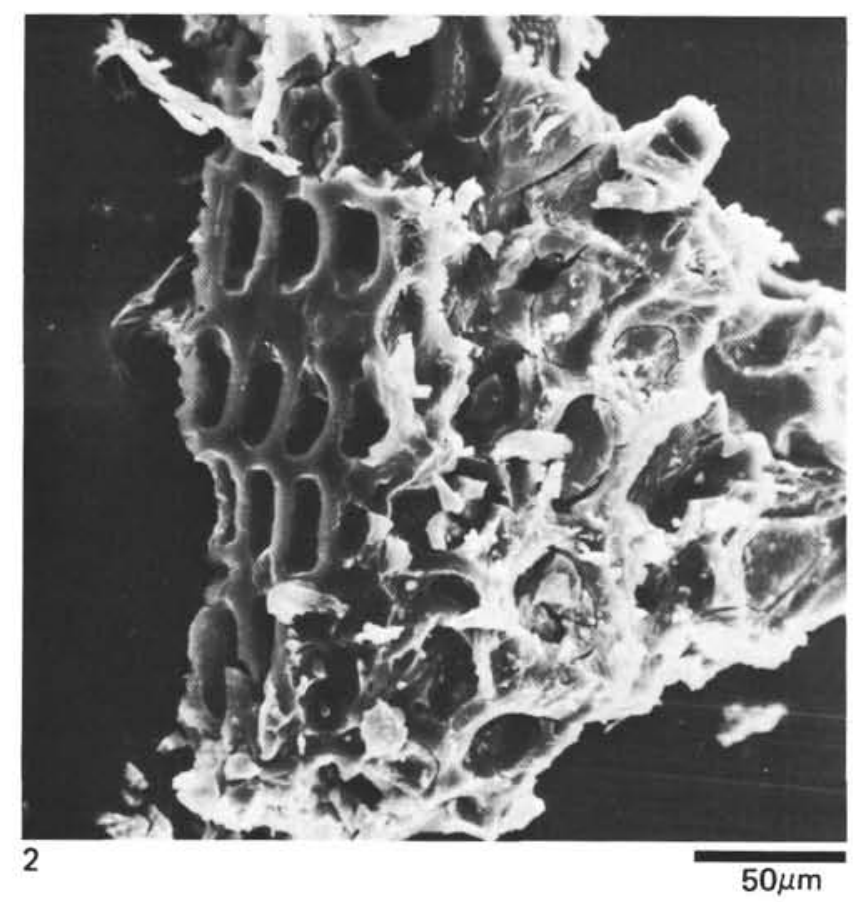

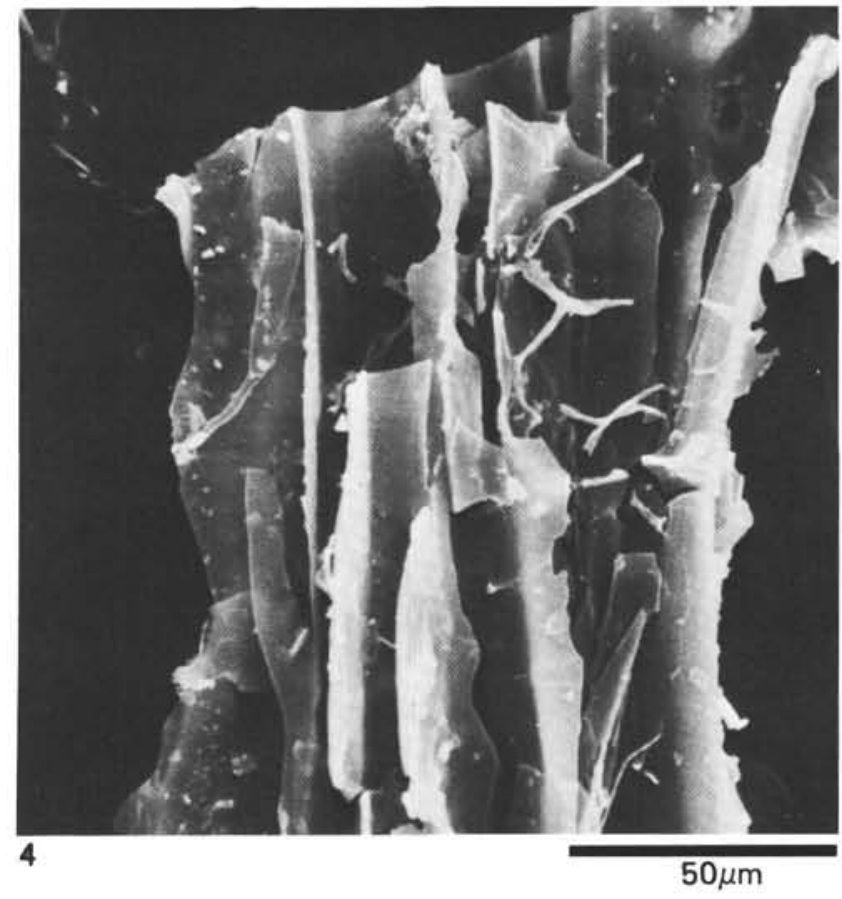

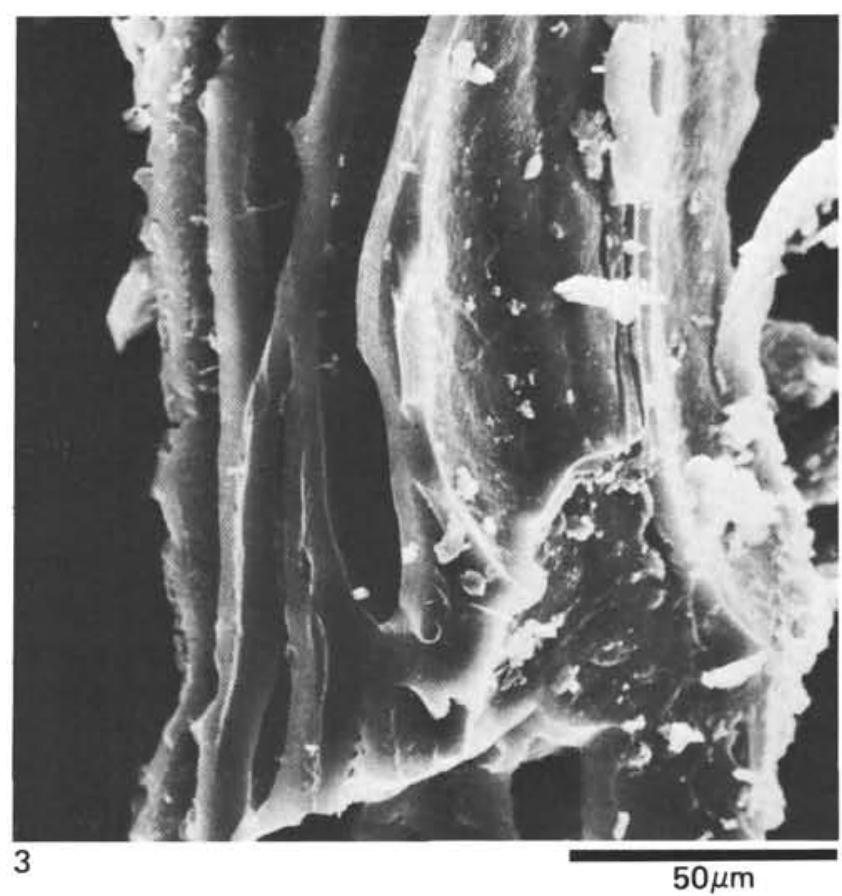

Figure 8. Black fragments of terrestrial plants from dark carbonaceous mudstone layers in lower Albian sediments. Photo 1: Sample 400A-66 3, $82 \mathrm{~cm}$. Photo 2:Sample 400A-66-1, $110 \mathrm{~cm}$. Photo 3: Sample 400A-66-1, 102 cm. Photo 4: given for comparison of a terrestrial plant from Recent peat (3000 yr). (Courtesy of Dr. A. Mariotti.) SEM.

the bottom water current activity rather than from a turbidity current. In the paleogeographic frame (Figure 1), such a periodic increase in the bottom water current activity, carrying a cold message (chlorite), suggests a periodic influx of northern water masses, spilling over a sill between the North American and European continental blocks, still joined. The imprint of this hydrodynamic regime is clearly recorded within the finely laminated black carbonaceous mudstones.
The cyclicity in the sedimentation is strikingly emphasized by the opposite trends of the abundance of the other two constituents of the sediment: clinoptilolite and calcite. The increase in clinoptilolite content, interpreted as an increase in available silica in surficial waters, indicates that the silica was brought from the cold silica-rich bottom water to the surface, through upwellings. This silica was readily metabolized by the planktonic siliceous organisms (mainly radiolarians), the productivity of which increased 

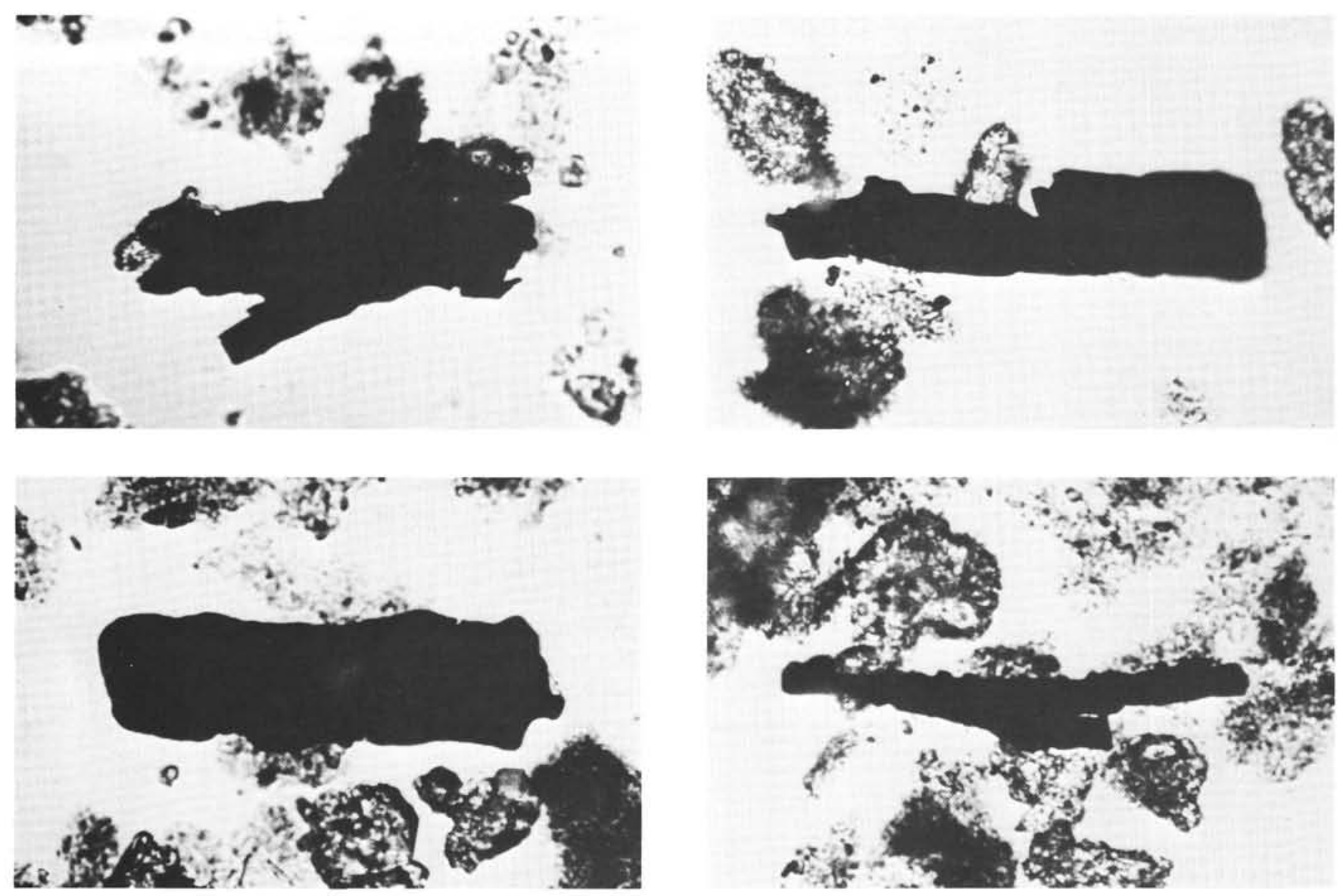

Figure 9. Black fragments of terrestrial plants from dark carbonaceous mudstone layers in lower Albian sediments (Sample $400 \mathrm{~A}-66-3,78 \mathrm{~cm})$. Compare with Figure 8. Optical microscope, $G=400(2 \mathrm{~cm}=50 \mu \mathrm{m})$.

markedly. As a result, large amounts of pelagic organic matter were released which, when oxidized, in turn generated large amounts of carbon dioxide, raising the aggressivity of the sea water toward calcium carbonate. Consequently, the biogenic calcitic remains (mainly coccoliths) dissolved rapidly, at times to complete disappearance, before reaching the bottom of the sea. This phenomenon is clearly recorded in the calcite abundance curve (Figure 2).

The absence of pyrite in both dark and lighter lithologies indicates that the medium always remained oxygenated; this is not surprising in the light of the above interpretation. We therefore conclude that the "black shales" were not deposited, here, in an anoxic environment.

\section{Hole 402A, Core 24}

The sequence studied (Figure 3 ) consists of alternations, on a metric scale, of dark carbonaceous mudstones, and slightly lighter carbonaceous marly limestones; this facies prevails throughout most Aptian/Albian deposits (see Site Chapter).

\section{Terrigenous Material}

The terrigenous material consists mainly of quartz (average content value $7 \%$ ), kaolinite $(5 \%)$, illite $(6 \%)$, and smectite $(15 \%)$. Feldspar, usually present in such an association, is, as in Hole $400 \mathrm{~A}$, absent. Because of its meager presence, the smectite was not submitted for DTA, but similarities (XRD) with the smectite from Hole 400A, Core 66 , Section 3 , and the chemical balance for $\mathrm{K}_{2} \mathrm{O}$ (XRF), suggest that we are dealing with the same kind of smectite, pedogenetically derived from micaceous and/or illitic material.

Quartz, illite, and kaolinite show similar trends in their discrete content variations, suggesting that calm conditions prevailed during the settling of the sediment. The highest values occur for both quartz and illite in the carbonaceous marly limestone zone within Section 4; the lowest values occur within the base of the dark carbonaceous mudstone layer (Section 4,10 cm). A remarkable correlation between illite and kaolinite appears.

The smectite abundance shows an approximately opposite trend to that of quartz and illite, smectite maxima occurring higher, in the sedimentary column, than those of quartz. This is particularly visible in the lower half of the core. The parts of the sedimentary sequence characterized by upward simultaneous decrease in quartz + illite content and increase in smectite content (for instance, Section 4, $55 \mathrm{~cm}$ to $10 \mathrm{~cm}$ ), are interpreted as progressive weakening in the water current transportation; this weakening, allowing the preferential settling of the finest particles (smectite), probably resulted from an increase in the height of the water column, and therefore these periods correspond to transgressive episodes. 


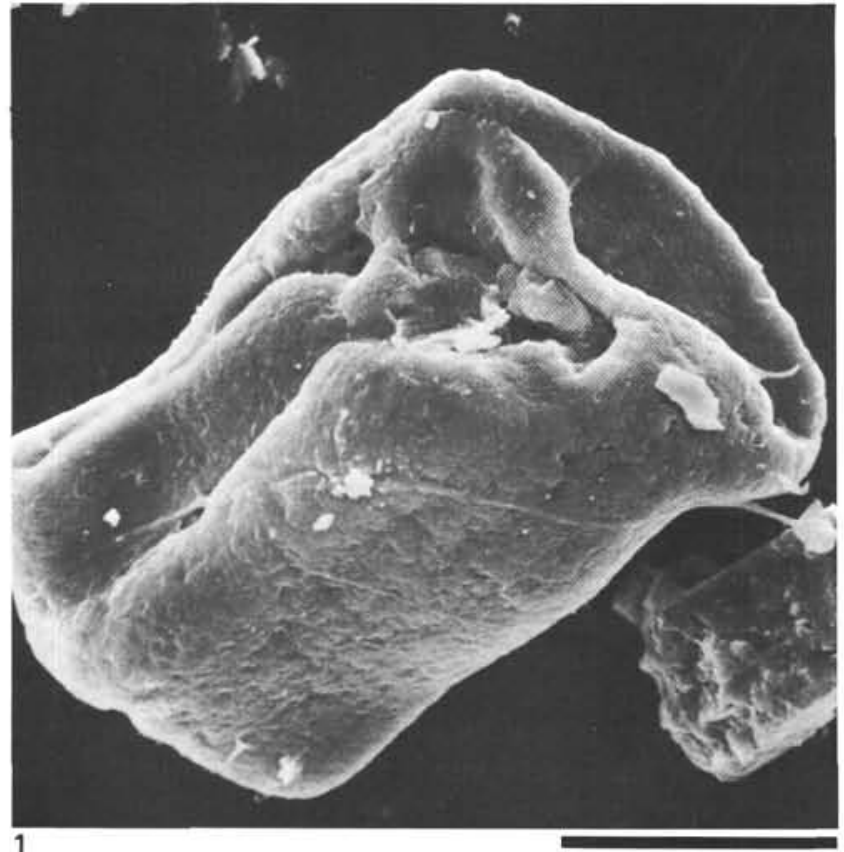

1

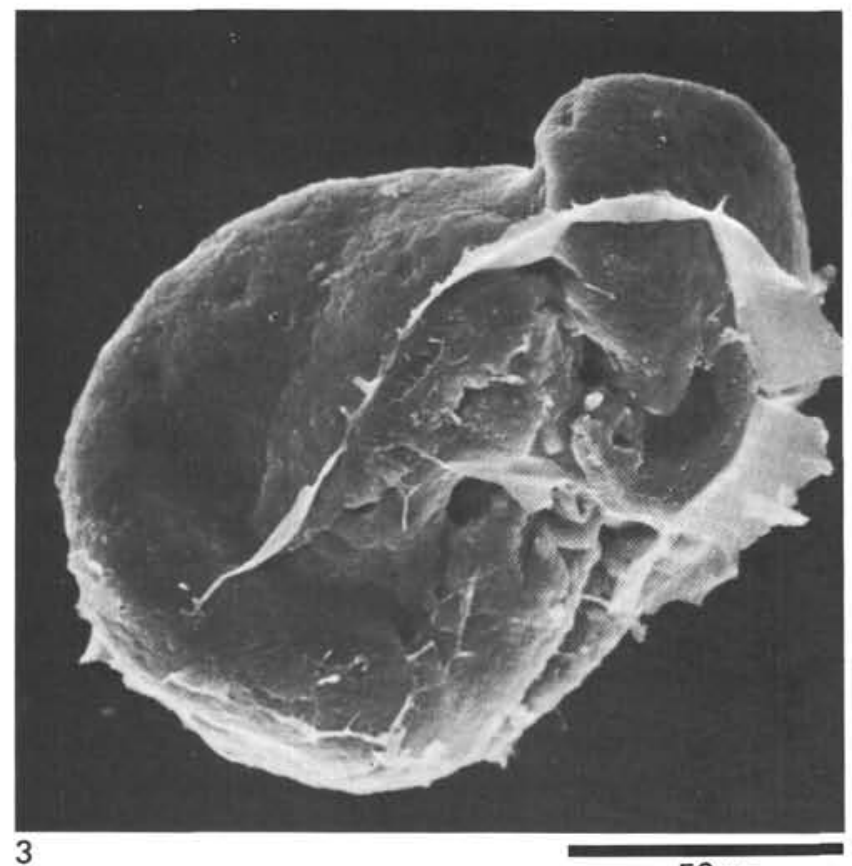

$50 \mu \mathrm{m}$

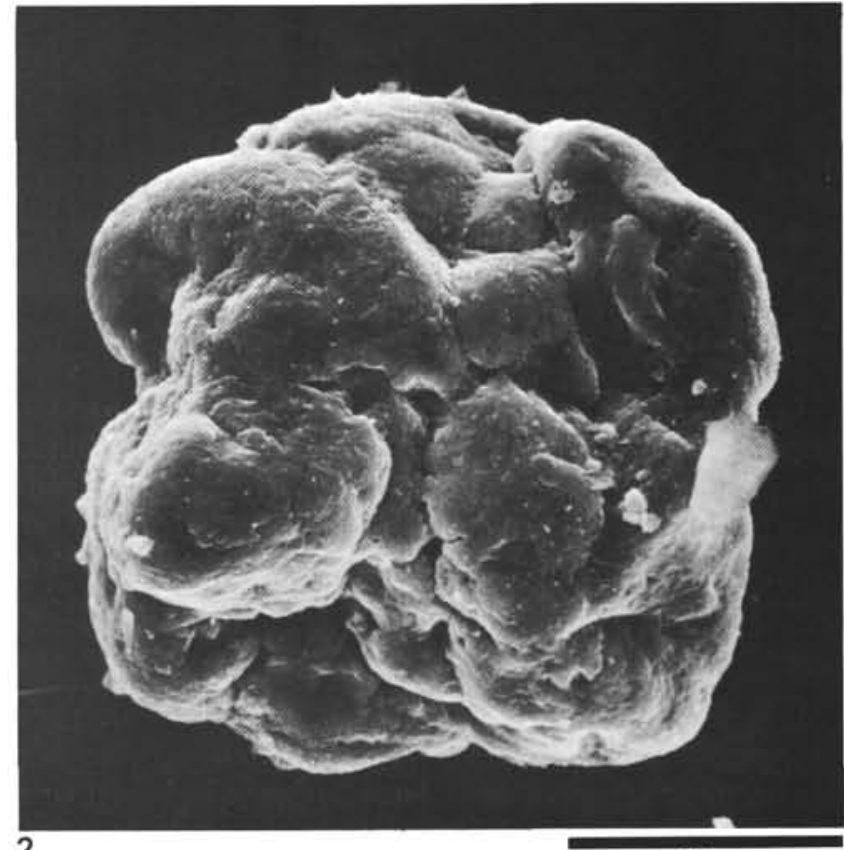

2

$50 \mu \mathrm{m}$

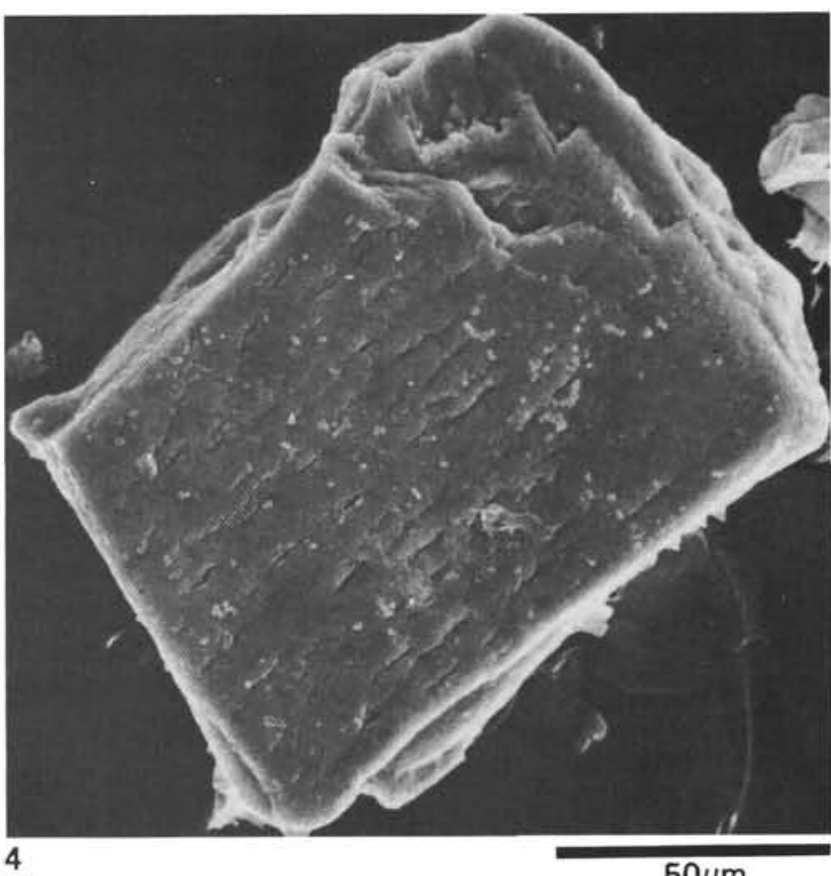

$50 \mu \mathrm{m}$

Figure 10. Examples of phosphate grains occurring preferentially in the greenish gray calcareous mudstone layers from lower Albian sediments. Photos 1 and 2: Sample 400A-66 3, 96 cm. Photo 3: Sample 400A-66-3, 111 cm. Photo 4: Sample 400A-66-3, $122 \mathrm{~cm}$ (bone fragment). Phosphorus and calcium were evidenced by X-ray microprobe. SEM.

The rather constant character of the composition of the terrigenous material suggests that settling of the material resulted from moderate to weak hydrodynamic activity, and that calm depositional conditions then prevailed. The highly mature character of the terrigenous material (absence of feldspar) indicates that the continental sources were probably quite distant and consisted of low landmasses, leveled by erosion.

\section{Opal-CT}

Opal-CT here essentially results from diagenetic transformation of siliceous sponge spicules, as shown by XRD analysis of isolated white spicules (Figure 11). The low B/A ratio of this opal-CT (Mélières, 1977) indicates a high degree of maturation for this biogenic silica. Opal-CT occurs throughout the core; its content values average 15 per cent and do not show large variation, indicating the 


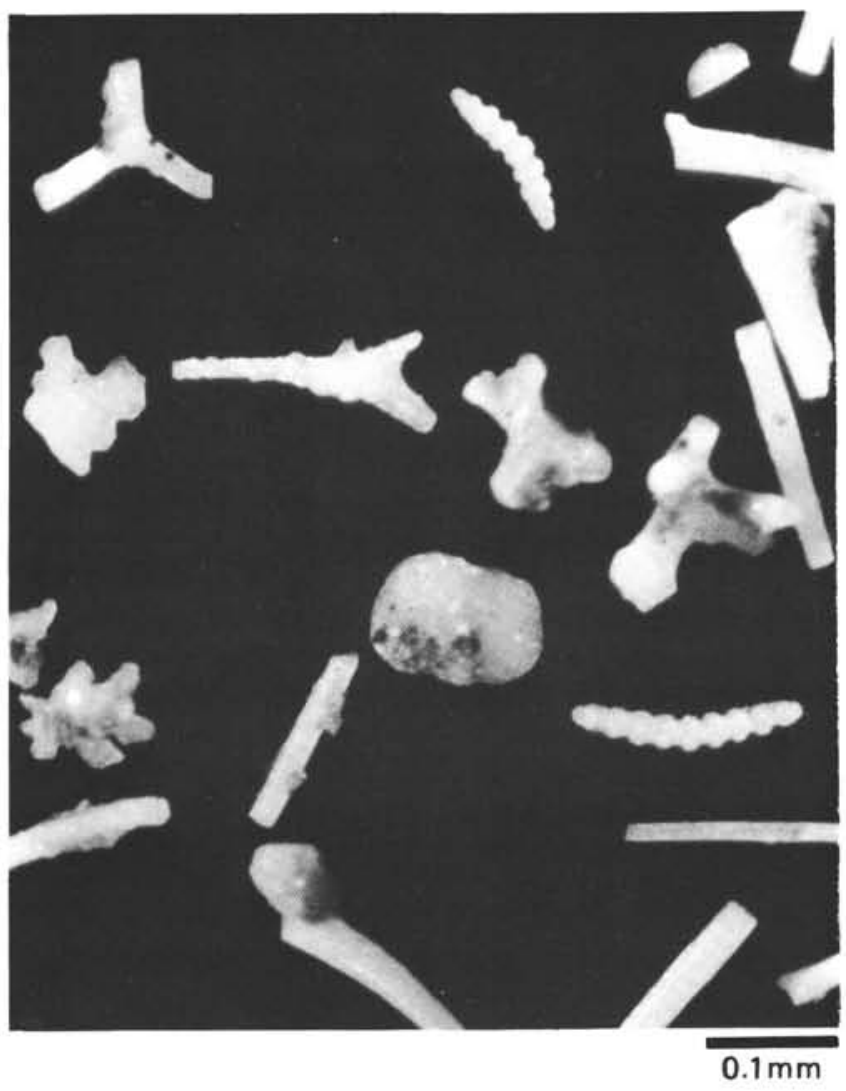

Figure 11. White to opalescent sponge spicules, diagenetically transformed into mature opal-CT (Sample 403-24-3, $23 \mathrm{~cm})$. Binocular, reflected light.

constancy of both amount of available silica in the sea water and depositional conditions. However, significant variations in the opal-CT content correlate closely, but in an opposite trend, with the smectite content variations; this may be interpreted either as a clay negative influence upon silica diagenesis (Lancelot, 1973), or more likely as a result of hydrodynamic sorting, since sponge spicules belong to the coarse fraction of the sediment.

\section{Clinoptilolite}

As in the case of the sediments studied from Hole 400A, the clinoptilolite results from infilling and transformation of radiolarian tests (Figure 12). The same comments can be made as for Hole 400A clinoptilolite. Since the mineral belongs to the coarse fraction of the sediment, it is not surprising that its abundance variations correlate closely to that of opal-CT. The occurrence of clinoptilolite throughout the core, and the lack of large variation in its abundance, indicate the constancy of the depositional conditions.

\section{Carbonates}

By contrast with Hole 400A (Core 66, Section 3), the carbonate minerals are here represented by several forms.

\section{Aragonite}

Aragonite occurs throughout the core, with a conspicuously constant value, ranging from 4 to 6 per cent
(Figure 3). This mineral comes mainly from ammonite shell debris, characterized by their irridescent coloration (lamellar layer); some of the debris, flattened through compaction, reaches $1 \mathrm{~cm}$ in size, and shows delicate costulations strikingly preserved. Beside ammonites, rare Inoceramus shell fragments (aragonite + calcite) occur, scattered in the sediment.

The consistent aragonite values indicate that the production of this mineral and its preservation during deposition remained constant. Its presence suggests settling in a shallow-water environment (few tens to hundreds of meters), where burial in suitable depositional conditions prevented any diagenetic process that would have resulted in its recrystallization and transformation into a more stable form (calcite). Light isotope studies on this exceptional material should yield valuable information about the paleoenvironment.

\section{Calcite}

Calcite occurs throughout the core; its content value ranges from 20 to 30 per cent. It consists of a mixture of two distinct mineralogical forms, as revealed by a detailed XRD study. The study (slow scan of [104], [108], and [116] diffraction peaks) establishes the co-existence of a poorly crystallized ${ }^{4}$ calcite characterized by a 2 per cent $\mathrm{mgCO}_{3}$ mole content (low-magnesium calcite), and an almost perfectly crystallized calcite completely devoid of magnesium.

The first form of calcite comprises mainly coccoliths and microspicules; the magnesium content, together with the low crystallinity, indicate that this biogenic calcite did not undergo any recrystallization. Because this form of calcite readily dissolves through deep-water deposition, the presence of such a poorly crystallized low-magnesium calcite suggests a settling in shallow-water environment, under suitable depositional conditions preventing post-depositional evolution (locked medium).

The second form of calcite is thought to be detrital (terrigenous), because of both crystallographical and optical data, and because recrystallization of biogenic calcitic remains is unlikely to have occurred here, as supported by the presence of aragonite.

The relative abundance of biogenic and detrital calcites was estimated on selected samples, through deconvolution of (104) calcite diffraction peak; the results are graphically represented by a dashed line in the "calcite" column (Figure 3).

After smoothing, for analytical imprecision and small variations, the calcite abundance curve may be divided in seven parts. Four of them consist of straight segments, defining a straight line from the base of the core (calcite $25 \%$ ), to the top (calcite $30 \%$ ); between these four straight segments, three parts show a more or less pronounced decrease in the calcite abundance. The latter zones correspond exactly to the dark carbonaceous mudstones, where the former correspond to the carbonaceous marly limestones. On the basis of the calcite abundance variation curve, the following

\footnotetext{
${ }^{4}$ We are dealing here with the lattice crystallinity measured by the width at half height of a diffraction peak.
} 


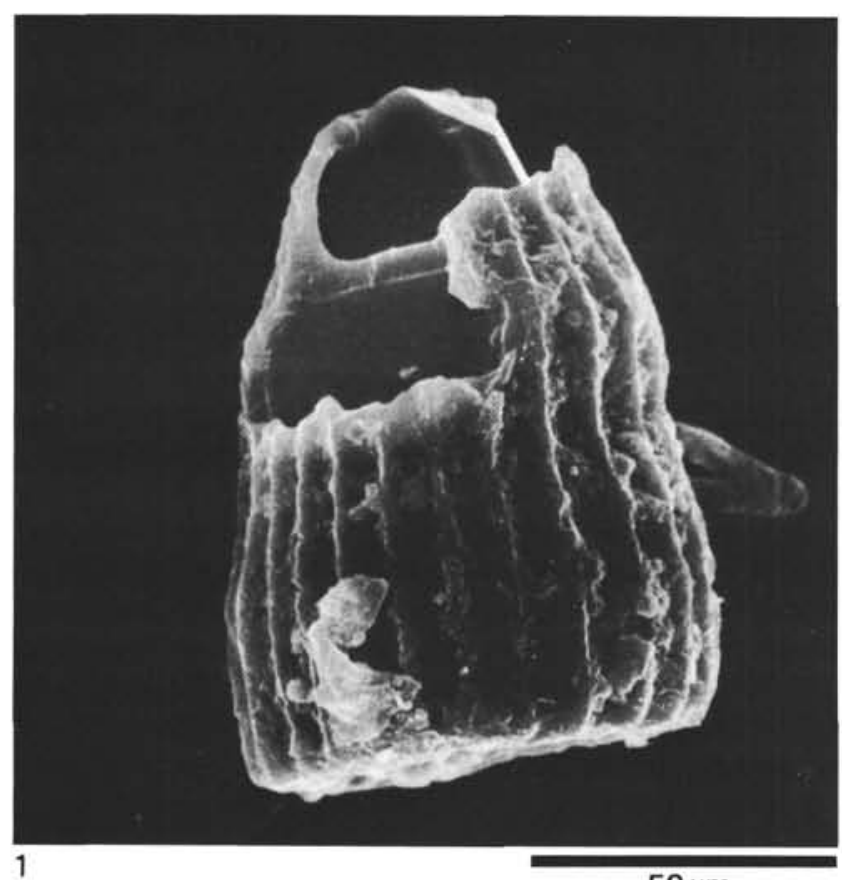

$50 \mu \mathrm{m}$
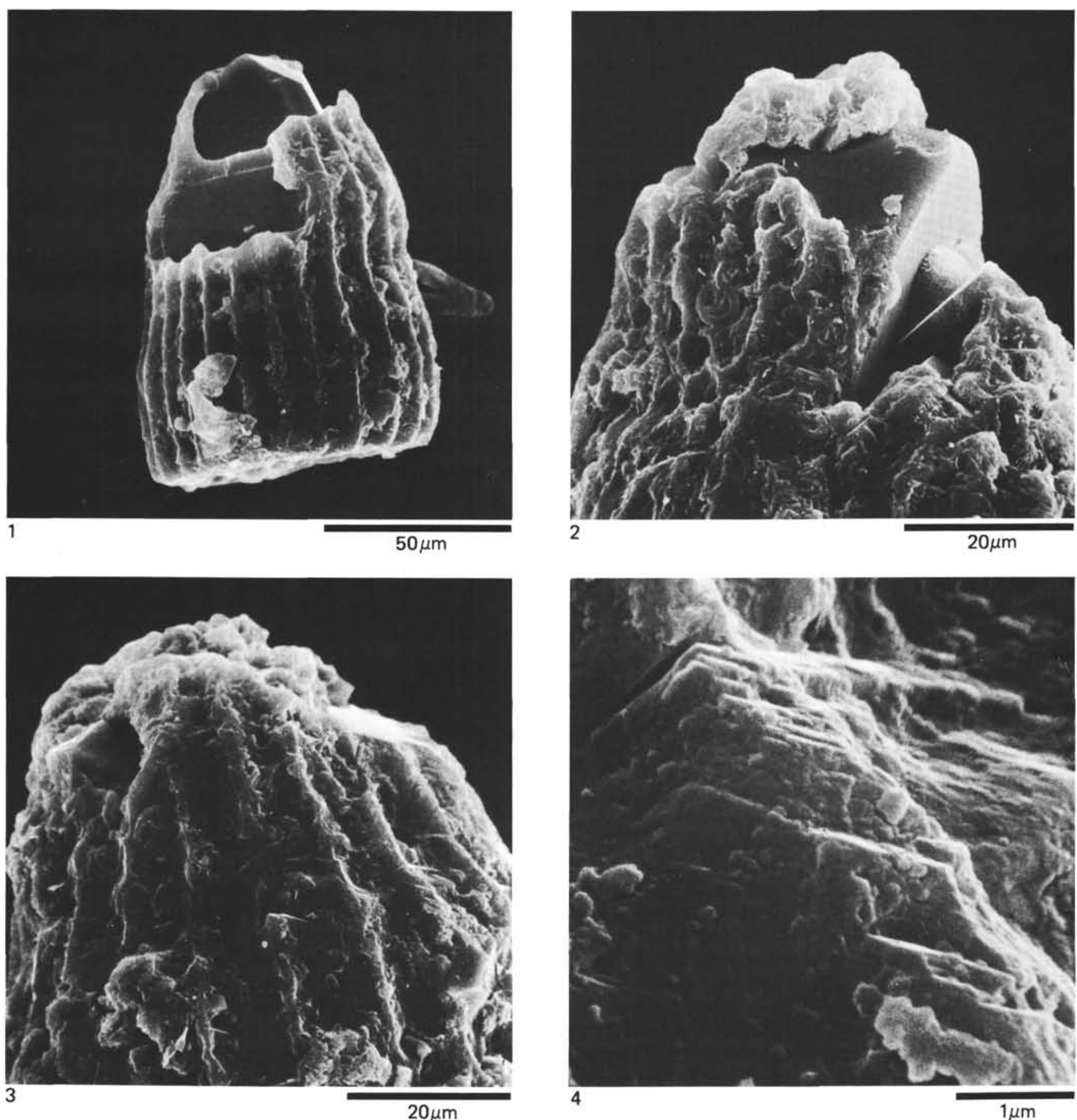

Figure 12. Radiolarian tests transformed in, and filled with, clinoptilolite. Photo 1: Sample 402A-24-1, $85 \mathrm{~cm}$. Photo 2: Sample 402A-242, $42 \mathrm{~cm}$. Photo 3: Sample 402A-24-2, $42 \mathrm{~cm}$, apical part of radiolarian test showing a crystal plane. Photo 4: detail of Photo 3 (center right) showing crystal planes throughout a costulation, and evidencing the clinoptilolite nature of the test. SEM. 
distinctions (ulteriorly referenced) from the top to the base of the core may be made:

\begin{tabular}{l} 
upper carbonaceous marly limestone zone: \\
Section $1,72 \mathrm{~cm}$ to Section $2,55 \mathrm{~cm}$ \\
upper carbonaceous mudstone zone: \\
Section $2,55 \mathrm{~cm}$ to Section $2,130 \mathrm{~cm}$ \\
upper-middle carbonaceous marly limestone zone: \\
Section $2,130 \mathrm{~cm}$ to Section $3,80 \mathrm{~cm}$ \\
middle carbonaceous mudstone zone: \\
Section $3,80 \mathrm{~cm}$ to Section $4,25 \mathrm{~cm}$ \\
lower-middle carbonaceous marly limestone zone: \\
Section $4,25 \mathrm{~cm}$ to Section $4,125 \mathrm{~cm}$ \\
lower carbonaceous mudstone zone: \\
Section $4,125 \mathrm{~cm}$ to Section $5,0 \mathrm{~cm}$ \\
lower carbonaceous marly limestone zone: \\
Section $5,0 \mathrm{~cm}$ to Section $5,35 \mathrm{~cm}$ \\
\hline
\end{tabular}

The relative abundance variation in the two constituents of the calcite phase (Figure 3 ) shows that the decrease in calcite abundance occurs at the expense of the biogenic calcite abundance. This decrease in the biogenic calcite abundance is interpreted as a decrease in the amount of biogenic calcite deposited, due to partial dissolution in the sea water before the settling. ${ }^{6}$.

Correlative to the decrease in biogenic calcite abundance, a slight increase appears in the detrital calcite abundance. Since this detrital calcite belongs to the fine fraction of the sediment, as shown by optical and XRD investigations on grain-sized fractions of selected samples, the slight increase in the detrital calcite abundance may be interpreted as resulting from a weakening of the water current transportation, allowing the preferential settling of the finest particles. This intrepretation is in good agreement with the trend of the smectite abundance variation, already interpreted in the same way.

The straight line, defined by the four straight segments of the calcite abundance curve, allows us to define a "steady state" in the carbonate sedimentation, characterized by the deposition of the carbonaceous marly limestones. This "steady state", was modified at times by a more or less pronounced decrease in the amount of biogenic calcite deposited. As indicated by the constant amount of aragonite deposited, it is thought that no change in the aggressivity of the sea water toward calcium carbonate occurred in the depositional environment and that the biogenic calcite dissolution must have taken place off the continental shelf. The biogenic calcite therefore is considered, here, to be an allochthonous constituent.

\section{Siderite}

Siderite occurs in minor amount (maximum 6\%) within the central part of the middle carbonaceous mudstone zone. The mineral is characterized by a low crystallinity and contains 10 per cent $\mathrm{CaCO}_{3}$ mole in its lattice (XRD) and is thought to be of primary origin. This assumption is supported by the fact that the siderite belongs mainly to the

\footnotetext{
${ }^{5}$ Due to its very discrete character, this zone was not recognized in shipboard investigations.

"This point was already discussed in the Hole 400A "carbonate" paragraph; the dissolution process, here offers much similarities and therefore will not be re-argued.
}

finest fraction of the sediment. Because siderite is unlikely to form in sea water (Berner, 1971, p. 199), the possibility of fresh water influence during the deposition of the siderite-bearing sediments should not be discarded.

The geochemical data show that small amounts of magnesium accompany the siderite. The origin of excess iron and magnesium (with regard to the "steady state") remains problematic; a possible contribution from altered mafic material is suggested.

\section{Pyrite and Gypsum}

Pyrite occurs throughout the core, in constant amount (average value $5 \%$ ), except for a sharp maximum in the middle of the upper carbonaceous mudstone zone (Section $2,95 \mathrm{~cm}$ ). SEM observations reveal that the pyrite habit occurs as perfect micrometric octahedrons, more or less aggregated (framboids), and always related to biogenic remains (Figure 13). This classical habit indicates that the pyrite is an early diagenetic product resulting from anaerobic bacterial activity in an anoxic environment within the newborn sediment. Such stressed conditions are thought to account for the preservation of aragonite and lowmagnesium calcite, both metastable carbonate forms.

The pyrite abundance peak, in the middle part of the upper carbonaceous mudstone zone, poses the problem of the origin of iron. Another iron maximum, although of a lesser importance, occurs in similar position within the middle part of the middle carbonaceous mudstone zone. Although poorly documented by chemical analysis data, the input of iron, together with small amount of magnesium, appears related closely to the impoverishment in biogenic calcite. A possible contribution from altered mafic material is again tentatively suggested; the point needs further investigation.

Gypsum occurs episodically in minor amount (less than $1 \%$ ), scattered throughout the core. Its variable abundance, closely related to that of pyrite, indicates that it is of secondary origin, and results from pyrite alteration.

\section{Amorphous Material}

\section{Organic Matter}

The organic matter consists mainly of black (carbonized) terrestrial plant fragments, as established by microscope investigation. These fragments are similar to those of the dark layers in Hole 400A, Core 66, Section 3. Their abundance, estimated from the organic carbon content value (Figure 3), ranges from 2 to 4 per cent, and the change is not clearly related to the biogenic calcite-impoverished zones. This suggests that the terrigenous organic material was delivered at a roughly constant rate, which $\mathrm{s}$ in good agreement with the calm and constant character of the sediment conditions.

\section{Other Amorphous Constituents}

The amount of amorphous material, estimated by subtracting the total amount of crystallized constituents from 100 , ranges from 10 to 20 per cent. Because of these low values, the detailed content variations of the amorphous material lack significance.

Using both mineralogical and geochemical data, attempt to characterize the composition of the amorphous material 

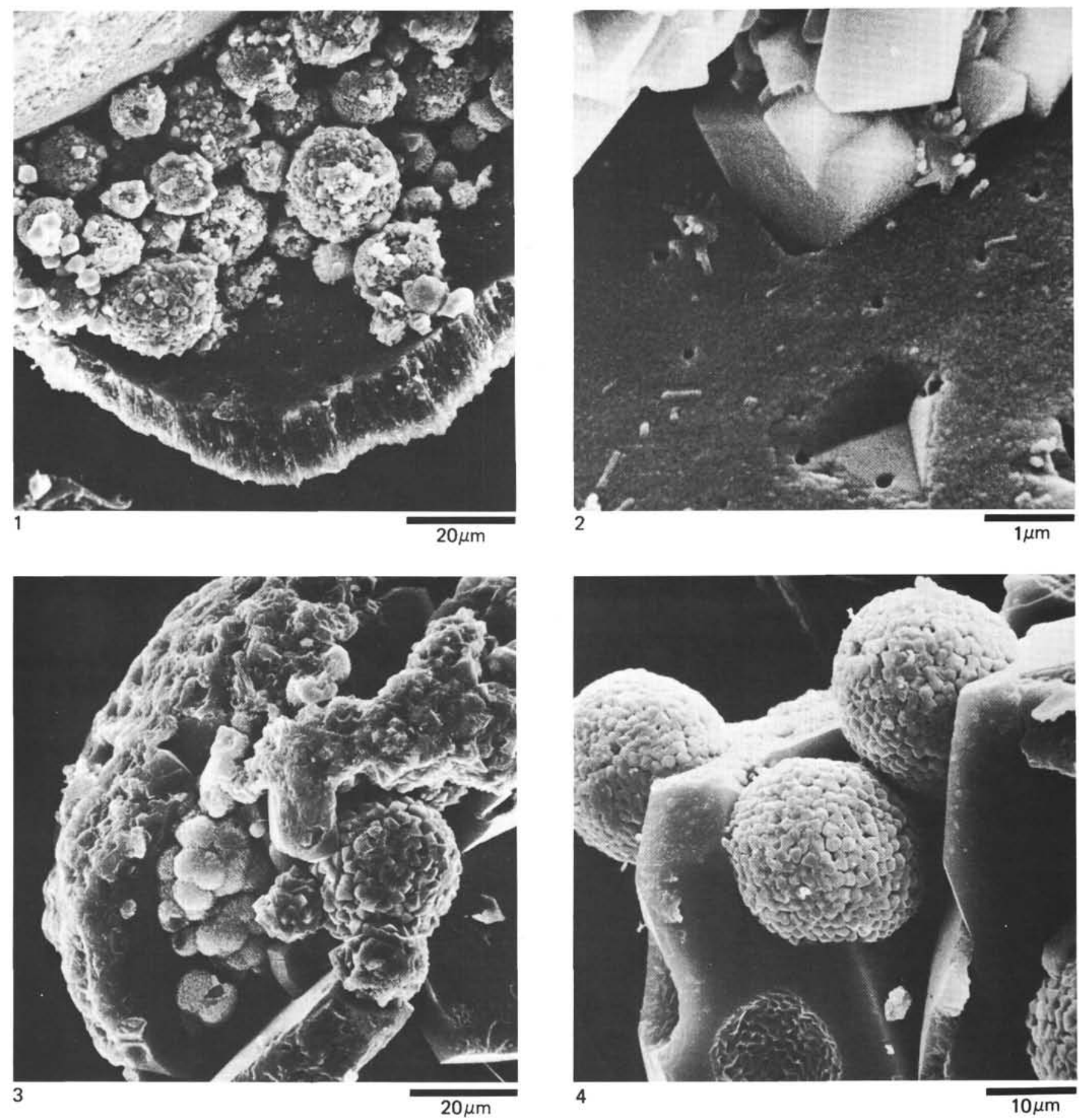

Figure 13. Framboidal pyrite in relation with biogenic remains in lower Albian sediments from the continental shelf. Photo 1:Sample 402A-24-2, $42 \mathrm{~cm}$, framboids in a foraminifer chamber. Photo 2; detail of Photo 1, showing pyrite octahedrons thrust into the calcitic inner wall of the foraminifer. Photo 3: Sample 402A-24-2, $42 \mathrm{~cm}$, framboidal pyrite, clinoptilolite, and opal-CT lepispheres in a radiolarian test. Photo 4: Sample 402A-24-1, $85 \mathrm{~cm}$, pyrite framboids cemented by clinoptilolite in a radiolarian test (detail). SEM. 
was made, in a manner similar to that for Hole 400A. This led to the following results:

\begin{tabular}{lc}
\hline \multicolumn{2}{c}{ Middle Carbonaceous Mudstone Zone } \\
Colloidal aluminosilicates & $12 \%$ \\
Biogenic silica & $1 \%$ \\
Organic matter & $\frac{3 \%}{16 \%}$ \\
Total & $15 \%$ \\
Average XRD value & \\
& \\
Lower-Middle Carbonaceous Marly Limestone Zone \\
Colloidal aluminosilicates & $9 \%$ \\
Organic matter & $3 \%$ \\
Total & $12 \%$ \\
Average XRD value & $10 \%$ \\
\hline
\end{tabular}

Although such an attempt may appear hazardous, it yields some indication about the rough composition of the amorphous material. For instance, biogenic silica does not seem to contribute significantly to the amorphous phase composition. This situation strongly contrasts with that for Hole 400A, Core 66, Section 3 sediments.

Although the origin of the aluminosilicates remains problematic, these constituents probably belong to the finest grained fraction of the sediment and, therefore, a maximum in their abundance suggests a period of weakening in the water current activity, allowing settling of the finest particles. Actually, the highest amorphous material content values correlate with the biogenic calcite-impoverished zones (carbonaceous mudstones); these zones are thought to correspond to deposition periods characterized by such a weakening in the water current activity, as suggested by the increase in amount of smectite deposited.

\section{Summary, Hole 402A}

The sediments constituting the sequence studied (Hole $402 \mathrm{~A}$, Core 24 , lower Albian) were deposited in shallow-water conditions, as indicated by the occurrence of both aragonite and low-magnesium calcite. The dominant feature of the sedimentation is the rather constant character of both environmental and depositional conditions, as indicated by the constancy of the mineralogical assemblage throughout the sequence.

The sediments deposited are very fine grained; the more than $40 \mu \mathrm{m}$ fraction constitutes 10 to 15 per cent of the sediment, and this fraction is very well sorted. The terrigenous material consists of quartz, illite, smectite, kaolinite, calcite, and carbonized plant fragments; the occurrence of kaolinite suggests that a moderate warm climatic influence prevailed then. The biogenic (or biogenic-derived) material consists of indigenous aragonite, opal-CT, and clinoptilolite (respectively, from ammonite shells, sponge spicules, and radiolarians), and allochthonous low-magnesium calcite (mainly from coccoliths). All this material settled on a weakly oxygenated sea bottom, under rather stagnant conditions, as suggested by the occurrence of pyrite throughout the sediment column; such stressed conditions, developed within the sediment below the first few centimeters, may account for the preservation of biogenic carbonates (aragonite and low-magnesium calcite) during diagenesis.

These features point to a "steady state" sedimentation, characterized by calm depositional conditions. This "steady state," which produced the carbonaceous marly limestones, was cyclically modified by two distinct phenomena. Chronologically (see Figure 3), the first event consists of a transgressive episode, as indicated by an upward simultaneous decrease in the amount of the coarsest particles deposited, and increase in the amount of the finest particles deposited. The second event, beginning in the upper half of the transgressive episode, consists of a more or less pronounced decrease in the amount of biogenic calcite sedimented, interpreted as resulting from a dissolution of this calcite, off the continental shelf. This second event resulted in the settling of the dark carbonaceous mudstones.

Occurrence of authigenic siderite, which is unlikely to form in normal marine conditions, within the central part of the thickest dark carbonaceous mudstone zone, poses a problem. There is a possibility of fresh-water influence, during the deposition of the siderite-bearing sediments.

\section{COMPARISON BETWEEN SITE 400 AND SITE 402}

\section{Depositional Environment}

The nature of the carbonate phases indicates that during early Albian time Site 402 was located on the continental shelf in a rather shallow-water environment, whereas Site 400 was characterized by deep-water conditions, but above the CCD. Because the distance between the two sites probably did not exceed $70 \mathrm{~km}$, it is inferred that Site 402 was located near the edge of the continental shelf, and Site 400 near the base of the continental slope.

A significant difference in the nature of the terrigenous material exists between Site 402 and Site 400 . Although on the whole, the terrigenous material at both sites consists of ubiquitous constituents (quartz, illite, smectite), kaolinite occurs only at Site 402 and chlorite only at Site 400 . This suggests that the two sites did not receive their terrigenous material (or at least a part of it) from the same continental sources. This is in good agreement with, and supports the above ascribed locations of the two sites. Moreover, it suggests (1) that the northern dense cold-water carrying chlorite did not enter the continental shelf, but flowed exclusively through a sill between North American and European continental masses; and (2) that terrigenous material was not transported from the continental shelf (kaolinite) toward the deeps. The presence of kaolinite at Site 402 indicates the influence of border landmasses (probably distant), where moderately warm climatic influences prevailed.

The difference in origin of the terrigenous material agrees well with the difference in the depositional conditions that are inferred from the features of the mineralogical assemblages. Although offering on the whole a quiet environment at both sites, bottom conditions were rather stagnant on the shelf, whereas at the deeper site the environment was constantly oxygenated and underwent cyclical increases in bottom current activity. 


\section{Cyclicity in the Sedimentation and Duration}

\section{of the Cycles}

Although the mineralogical associations are not the same at Site 402 and Site 400 , the variation trends in mineral abundances points up the cyclic character of the sedimentation at both sites. According to the calculated sedimentation rates in the Albian of $24 \mathrm{~mm} / 1000 \mathrm{yr}$ at Site 402 and $7 \mathrm{~mm} / 1000 \mathrm{yr}$ at Site 400 (see Site Chapters), estimations can be made (see Table 1). The calculations are based on an average sedimentation rate value, and it is necessary to make a suitable correction because of the different lithologies involved. Compared to the calcareous facies, the black facies probably represents a condensed sequence of sediments, and thus would involve a longer time span than that indicated by the calculation; the calcareous facies consequently would represent a shorter period than here indicated. For the present, it is not possible to evaluate such a correction.

Cycle duration appears to be of the same order of magnitude at both sites. Because the sections are of contemporary age, we suggest that the cyclicity at both sites was controlled by the same phenomenon.

\section{Nature and Cause of the Cyclic Sedimentation: Imprint on the Sedimentary Record}

The main event responsible for the cyclic sedimentation appears to have consisted of periodic influxes of cold silica-rich waters coming from nothern areas, and flowing into the trough between the European and Iberian continental masses (Figure 1). In response to the increase in the amount of available silica, introduced into surficial waters through upwellings, the productivity of siliceous planktonic organisms (mainly radiolarians) increased markedly. The result was a settling of vast amounts of radiolarian tests, later transformed in clinoptilolite through

TABLE 1

Comparison of Sedimentation Cycles at Sites 400 and 402

\begin{tabular}{|c|c|c|c|}
\hline \multirow[b]{2}{*}{ Lithologic Units } & \multirow{2}{*}{$\begin{array}{l}\text { Thickness } \\
(\mathrm{mm})\end{array}$} & \multicolumn{2}{|c|}{ Duration (yr) } \\
\hline & & Zones & Cycles \\
\hline \multicolumn{4}{|l|}{ Site 402 (Hole 402A, Core 24) } \\
\hline $\begin{array}{l}\text { Upper carbonaceous } \\
\text { marly limestone zone }\end{array}$ & 1300 & 54,000 & $>54,000$ \\
\hline $\begin{array}{l}\text { Discrete upper carbonaceous mudstone } \\
\text { zone }\end{array}$ & 800 & 30,000 & \multirow{2}{*}{72,000} \\
\hline $\begin{array}{l}\text { Upper middle carbonaceous marly } \\
\text { limestone zone }\end{array}$ & 1000 & 42,000 & \\
\hline Middle carbonaceous mudstone zone & 950 & 40,000 & \multirow[b]{2}{*}{82,000} \\
\hline $\begin{array}{l}\text { Lower middle carbonaceous marly } \\
\text { limestone zone }\end{array}$ & 1000 & 42,000 & \\
\hline Lower carbonaceous mudstone zone & 250 & 10,500 & \multirow[b]{2}{*}{$>23,000$} \\
\hline $\begin{array}{l}\text { Lower carbonaceous marly limestone } \\
\text { zone }\end{array}$ & 350 & 12,500 & \\
\hline \multicolumn{4}{|l|}{ Site 400 (Hole 400A, Core 66, Section 3) } \\
\hline Upper calcareous mudstone zone & 160 & 23,000 & $>23,000$ \\
\hline $\begin{array}{l}\text { Upper black carbonaceous mudstone } \\
\text { zone }\end{array}$ & 150 & 21,000 & \multirow[t]{2}{*}{92,000} \\
\hline Lower calcareous mudstone zone & 500 & 71,000 & \\
\hline $\begin{array}{l}\text { Lower black carbonaceous mudstone } \\
\text { zone }\end{array}$ & 150 & 21,000 & $>21,000$ \\
\hline
\end{tabular}

diagenesis (Site 400). This high productivity was restricted to the upwelling zones, where the total amount of dissolved silica was readily metabolized; this productivity did not develop on the continental shelf (Site 402), as evidenced by the lack of increase in silica minerals (opal-CT and clinoptilolite) diagenetically derived from siliceous biogenic remains.

Because of the high biologic productivity, a large amount of planktonic organic matter was released in the sea water. As a result of the oxidation of this organic matter, much carbon dioxide was produced, resulting in significant dissolution of calcium carbonate; planktonic calcitic remains (mainly coccoliths) readily dissolved and did not reach the bottom of the sea, which resulted in marked calcite minima coinciding with the maxima of clinoptilolite (Site 400)?

Correlatively, the amount of planktonic calcitic remains, carried toward the continental shelf by surficial currents, decreased markedly; the decrease is well recorded on the shelf (Site 402) within the dark carbonaceous mudstone zones, which appear to be contemporary with the black carbonaceous mudstone layers deposited in the deep Site 400. The fact that aragonitic shell debris did not dissolve on the shelf indicates that the surficial waters entering the shelf were saturated with calcium carbonate, because the chain reaction silica $\rightarrow$ radiolarians $\rightarrow$ organic matter $\rightarrow$ carbon dioxide $\rightarrow$ calcite dissolution, occurred in the upwelling zones off the continental shelf.

\section{Triggering of the Process Responsible for the Settling of the Dark Sediments}

Comparison of the sedimentary processes at both sites evidences that the deposition of the dark carbonaceous mudstones on the continental shelf, and the black carbonaceous mudstones in the deep, occurred simultaneously as a response to a deep, cold-water influx.

The cause of the influx of northern cold water is in question, the answer to which is in the sedimentary record at Site 402. There a cyclic transgressive episode occurred within the same period as that of the influx of the northern water, but before the beginning of the deposition of the carbonaceous mudstones (Site 402). In other words, it occurred before the establishment of the inflow of northern cold water to Site 400 . The inflow began when the deep northern cold water, within the northern area, reached the level of the sill between North American and European continental masses. The triggering of the northern cold-water inflow appears to be related to a relative rise of sea level, resulting in transgression.

It follows that the end of the deposition of the dark layers at both sites is a consequence of a regressive phase which interrupted the flow of northern cold water. As long as the latter water was prevented from flowing into the trough, the depositional conditions at both sites remained calm and the

\footnotetext{
${ }^{7}$ Because coccoliths are known to develop preferentially in warm water (McIntyre et al., 1967), the input of deep cold water through upwellings may have been responsible for a decrease in the biogenic calcite production. This process would have acted in the same way as calcite dissolution, reinforcing the decrease in the amount of calcite deposited.
} 


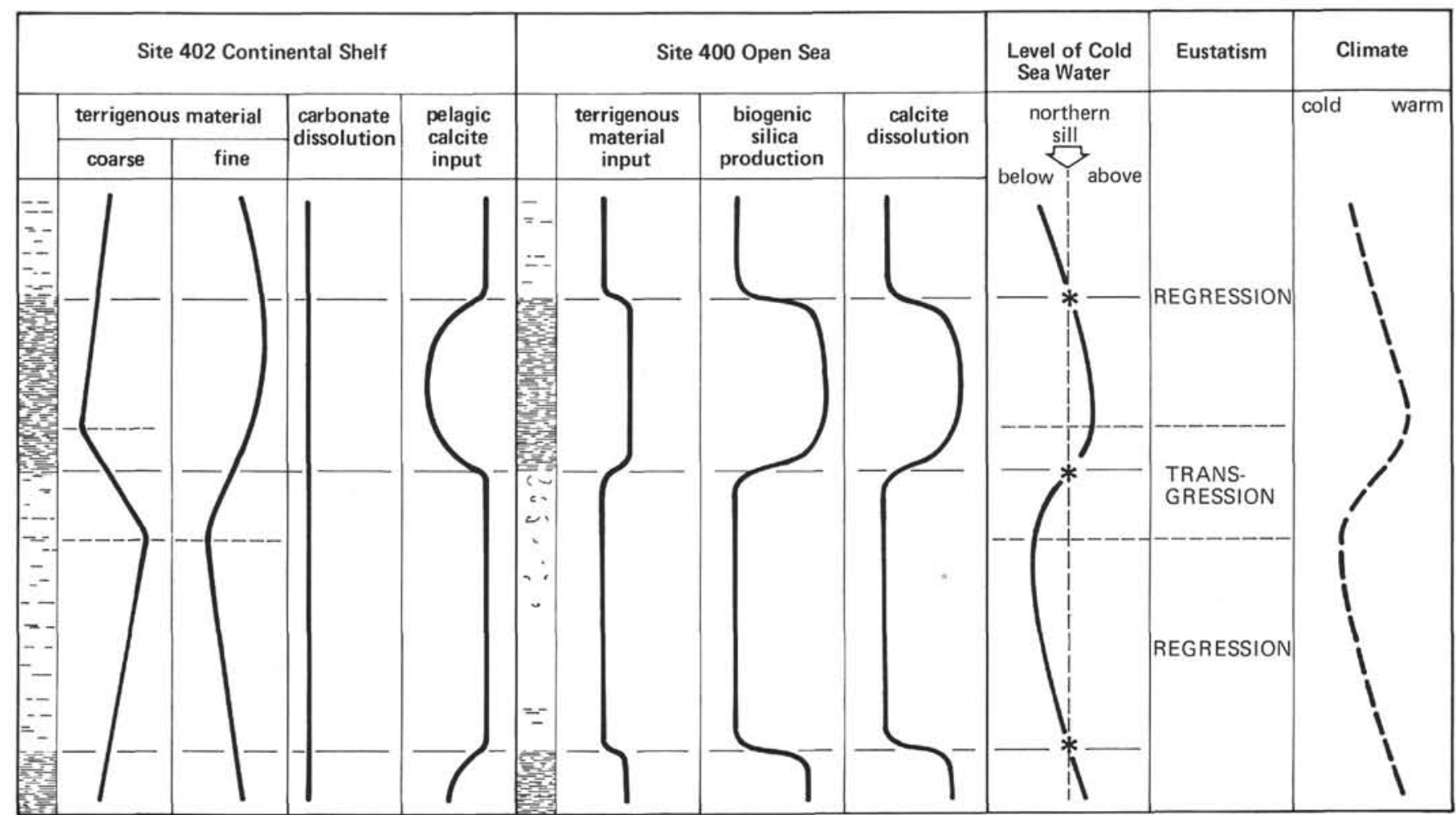

Figure 14. Main schematized sedimentological features observed in lower Albian deposits, and their interpretation (curves show increase to the right). Compare with figures 2 and 3; see text for comments.

carbonaceous marly limestones settled on the shelf while the greenish gray calcareous mudstones settled at the base of the continental slope and a "steady state" in the sedimentation existed.

\section{Cause of Transgressions and Regressions}

The interpretation of this cyclic oscillation as resulting from a cyclic climatic change is suggestive. Comparison of the phenomenon with climatic cycles of the past 600,000 years shows two similarities. As established by Ruddiman and McIntyre (1976), seven major climatic cycles occurred in the northern Atlantic area during that period, with an average cycle duration of 84,000 years; the average duration of a cycle in early Albian time (this study) is 82,000 years, calculated on three cycles. In general, the seven late Pleistocene climatic cycles shows a more or less "saw-toothed", geometry, with gradual glacial build-up (regression) followed by rapid deglaciation (transgression). A similar "sawtoothed" shape is evidenced through oxygen-isotope studies in late Pleistocene Pacific sediments (Shackleton and Updyke, 1976). In early Albian time, the transgressive period appears shorter than the regressive one (Figure 14).

Further investigations, on a larger number of Aptian/Albian cycles, of course are needed to test the hypothesis.

\section{GENERAL CONCLUSION}

The cyclic occurrence of dark carbonaceous mudstone layers ("black shales") in Aptian-Albian sediments from the Bay of Biscay, appears to have resulted from a periodic change in the environmental conditions, induced by climatic cycles, the period of which is very similar to that of the late Pleistocene climatic cycles. This suggests perennial existence of regular climatic variations from (at least) the Early Cretaceous until the present.

\section{ACKNOWLEDGMENTS}

The author is particularly indebted to Dr. L. Montadert (Institut Français du Pétrole) who personally supervised the remarkable set of samples during Leg 48, made frequent and valuable comments, and reviewed the final manuscript. Dr. G Deroo (Institut Français du Pétrole) and Dr. C. Boltenhagen (Société Nationale Elf Aquitaine) are gratefully acknowledged for their assistance in organic carbon and geochemical analysis, respectively. SEM investigations were carried out at Laboratoire de Micropaléontologie de l'Université Pierre et Marie Curie, thanks to the assistance of $\mathrm{Dr}$. Ph. Blanc. This study benefited from helpful discussions with Pr. Ph.C. de Graciansky (Ecole des Mines de Paris). Pr. R. Létolle (Université Pierre et Marie Curie) reviewed the final manuscript.

\section{REFERENCES}

Barker, P.F., Dalziel, I.W.D., et al., 1976. Initial Reports of the Deep Sea Drilling Project, v.36: Washington (U.S. Government Printing Office).

Berner, A.B., 1971. Principles of chemical geology: New York (McGraw Hill.)

Bolli, H.M., Ryan, W.B.F., et al., 1977. Initial Reports of the Deep Sea Drilling Project, v.40: Washington (U.S. Government Printing Office).

Hayes, D.E., Pimm, A.C., et al., 1972. Initial Reports of the Deep Sea Drilling Project, v. 14: Washington (U.S. Government Printing Office).

Lancelot, Y., 1973. Chert and silica diagenesis in sediments from the Central Pacific. In Winterer, E.L., Ewing, J.I., et al., Initial Reports of the Deep Sea Drilling Project, v. 17: Washington (U.S. Government Printing Office), p. 377-404. 
Lancelot, Y., Seibold, E., et al., 1978. Initial Reports of the Deep Sea Drilling Project, v.41: Washington (U.S. Government Printing Office).

McIntyre, A., Bé, A.W.H., and Preikstas, R., 1967. Coccoliths and the Pliocene-Pleistocene boundary. Progress in Oceanography, v.4, The Quaternary History of the Ocean Basins: London and New York (Pergamon Press), p. 3-25.

Mélières, F., 1974. Recherches sur la dynamique sédimentaire du Golfe de Cadix (Espagne). Thèse, Université Pierre et Marie Curie, Paris, p. 10-120.

, 1978. X-ray mineralogy studies, Leg 41, Deep Sea Drilling Project, eastern North Atlantic Ocean. In Lancelot, Y., Seibold, E., et al., Initial Reports of the Deep Sea Drilling Project, v. 41: Washington (U.S. Government Printing Office), p. $1065-1086$.
Olivet, J.L., 1978. Nouveau modèle d'évolution de l'Atlantique Nord et Central. Thèse, Université Pierre et Marie Curie, Paris.

Ruddiman, W.F., and McIntyre, A., 1976. Northeast Atlantic paleoclimatic changes over the 600,000 years. In Investigations of late Quaternary paleoceanography and paleoclimatology, Geol. Soc. Am., Mem. 145, p. 111-146.

Shackleton, N.J., and Opdyke, N.D., 1976. Oxygen-isotope and paleomagnetic stratigraphy of Pacific Core V28-239 late Pliocene to latest Pleistocene. In Investigations of late Quaternary paleoceanography and paleoclimatology, Geol. Soc. Am., Mem. 145, p.449-464.

Trask, P.D., 1939. Organic content of recent marine sediments. In Trask, P.D., (Ed.), Recent marine sediments: Tulsa, Okla. (American Association of Petroleum Geologists), p. 428-453. 